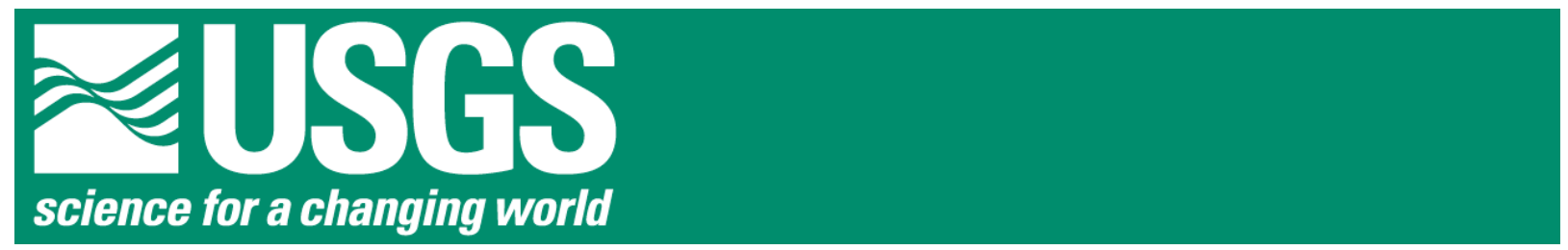

\title{
Vegetation and Substrate on Aeolian Landscapes in the Colorado River Corridor, Cataract Canyon, Utah
}

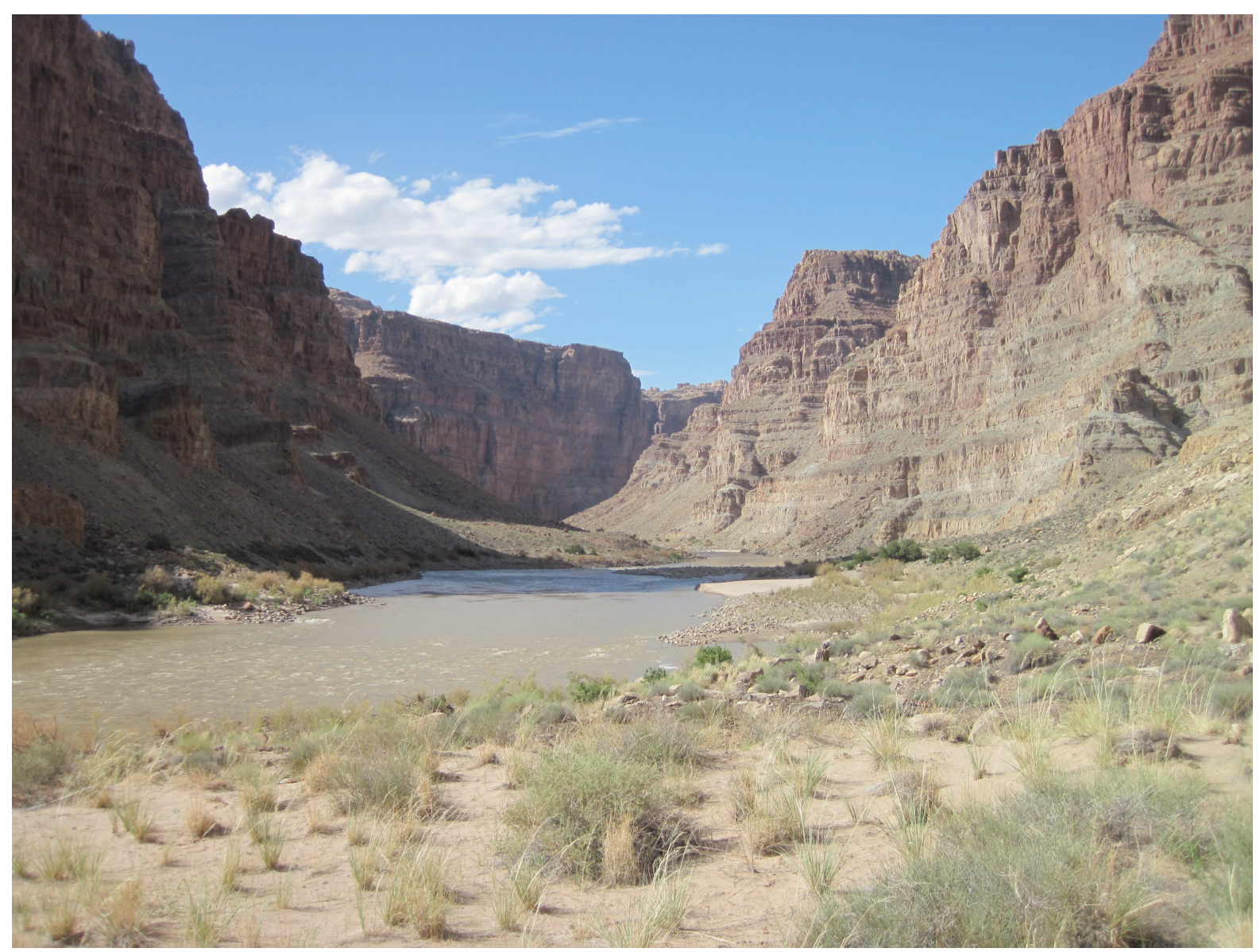

Open-File Report 2010-1273

U.S. Department of the Interior

U.S. Geological Survey 



\section{Vegetation and Substrate on Aeolian Landscapes in the Colorado River Corridor, Cataract Canyon, Utah}

By Amy E. Draut and Elizabeth R. Gillette

Open-File Report 2010-1273 


\section{U.S. Department of the Interior \\ KEN SALAZAR, Secretary}

\section{U.S. Geological Survey \\ Marcia K. McNutt, Director}

U.S. Geological Survey, Reston, Virginia 2010

For product and ordering information:

World Wide Web: http://www.usgs.gov/pubprod

Telephone: 1-888-ASK-USGS

For more information on the USGS-the Federal source for science about the Earth,

its natural and living resources, natural hazards, and the environment:

World Wide Web: http://www.usgs.gov

Telephone: 1-888-ASK-USGS

Suggested citation:

Draut, A.E., and Gillette, E.R., 2010, Vegetation and substrate on aeolian landscapes in the Colorado River corridor, Cataract Canyon, Utah: U.S. Geological Survey Open-File Report 2010-1273, 61 p. and 14 spreadsheets [http://pub.usgs.gov/of/2010/1273/].

Any use of trade, product, or firm names is for descriptive purposes only and does not imply endorsement by the U.S. Government.

Although this report is in the public domain, permission must be secured from the individual copyright owners to reproduce any copyrighted material contained within this report. 


\section{Contents}

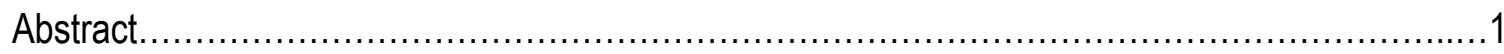

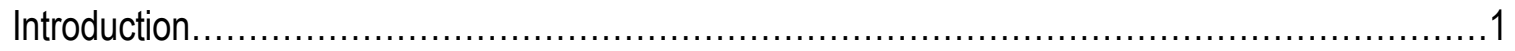

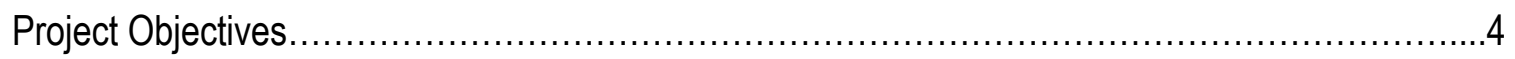

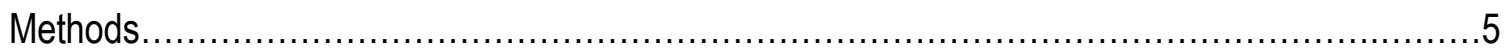

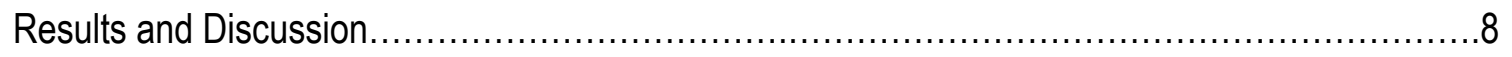

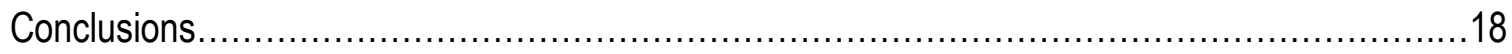

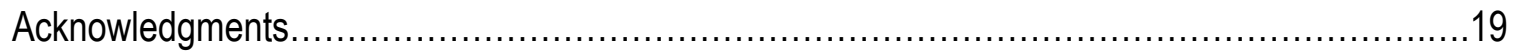

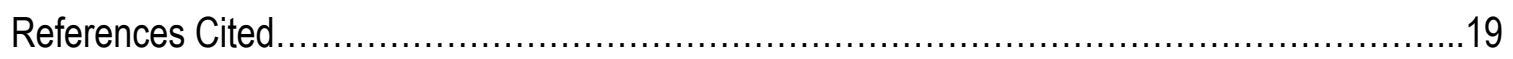

\section{Figures}

1. Study sites in the Colorado River through Cataract Canyon, Utah. ...............................

2. Scale diagram of "pod" configuration used to map vegetation and substrate in

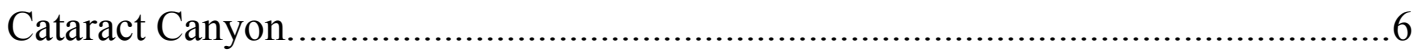

3. Measuring vegetation and substrate properties on an aeolian landscape in Cataract

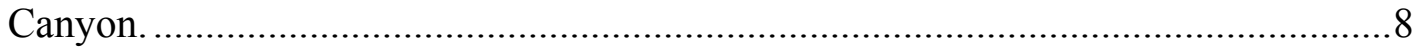

4. Plots showing total vegetation cover. ………………...........................................11

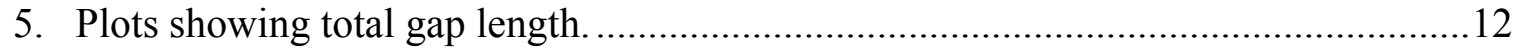

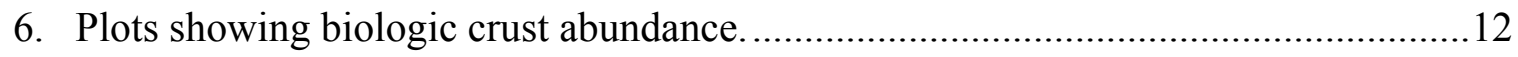

7. Plots showing substrate composition at each of the 13 study sites...............................13

8. Plots showing coverage of invasive Russian thistle (Salsola sp.)...............................14

9. Plots showing coverage of invasive brome grasses (Bromus sp.)..............................14

10. Plots showing coverage of invasive tamarisk (Tamarix sp.)......................................15

11. Plots showing vegetation composition at each of the 13 study sites, identifying the proportion of Tamarix, Bromus, and Salsola .........................................................16 


\section{Tables}

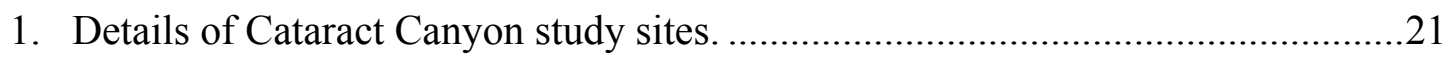

2. Vegetation cover and substrate properties measured at Site 1..............................22

3. Vegetation cover and substrate properties measured at Site 2...............................25

4. Vegetation cover and substrate properties measured at Site 3 ................................28

5. Vegetation cover and substrate properties measured at Site 4................................31

6. Vegetation cover and substrate properties measured at Site 5 .................................35

7. Vegetation cover and substrate properties measured at Site $6 \ldots \ldots \ldots \ldots \ldots \ldots \ldots \ldots \ldots \ldots \ldots . . . . .38$

8. Vegetation cover and substrate properties measured at Site 7................................41

9. Vegetation cover and substrate properties measured at Site 8

10. Vegetation cover and substrate properties measured at Site 9 ................................47

11. Vegetation cover and substrate properties measured at Site 10..............................50

12. Vegetation cover and substrate properties measured at Site 11............................53

13. Vegetation cover and substrate properties measured at Site 12.............................56

14. Vegetation cover and substrate properties measured at Site 13..............................59 


\title{
Vegetation and Substrate on Aeolian Landscapes in the Colorado River Corridor, Cataract Canyon, Utah
}

By Amy E. Draut ${ }^{1}$ and Elizabeth R. Gillette ${ }^{2}$

\begin{abstract}
Vegetation and substrate data presented in this report characterize ground cover on aeolian landscapes of the Colorado River corridor through Cataract Canyon, Utah, in Canyonlands National Park. The 27-km-long Cataract Canyon reach has undergone less anthropogenic alteration than other reaches of the mainstem Colorado River. Characterizing ecosystem parameters there provides a basis against which to evaluate future changes, such as those that could result from the further spread of nonnative plant species or increased visitor use. Upstream dams have less effect on the hydrology and sediment supply in Cataract Canyon compared with downstream reaches in Grand Canyon National Park. For this reason, comparison of these vegetation and substrate measurements with similar data from aeolian landscapes of Grand Canyon will help to resolve the effects of Glen Canyon Dam operations on the Colorado River corridor ecosystem.
\end{abstract}

\section{Introduction}

Most areas of the Colorado River corridor, in the southwestern United States, are affected by human-caused alteration, whether from changes in river flow and sediment supply caused by upstream dams, from introduced plant and animal species, or from land use in the watershed that includes

\footnotetext{
${ }^{1}$ U.S. Geological Survey Pacific Coastal and Marine Science Center, Santa Cruz, CA 95060

${ }^{2} 2$ Thissell Rd., Ossipee, NH 03864
} 
agricultural and rangeland practices. The $27-\mathrm{km}$ reach of the Colorado River corridor through Cataract Canyon, Utah (fig. 1), represents the least altered region along the mainstem Colorado River below its confluence with the major Green River tributary. Because its hydrology and sediment supply are less affected by upstream dams than are any reaches of the Colorado River farther downstream, and because the immediately surrounding watershed is nearly undeveloped as part of Canyonlands National Park, Cataract Canyon provides an opportunity to study natural resources in an ecosystem less disturbed than in many other parts of the Colorado River corridor. This field study quantified ground cover (vegetation and substrate) on landscapes of Cataract Canyon that are characterized by aeolian (wind-blown) sand. 


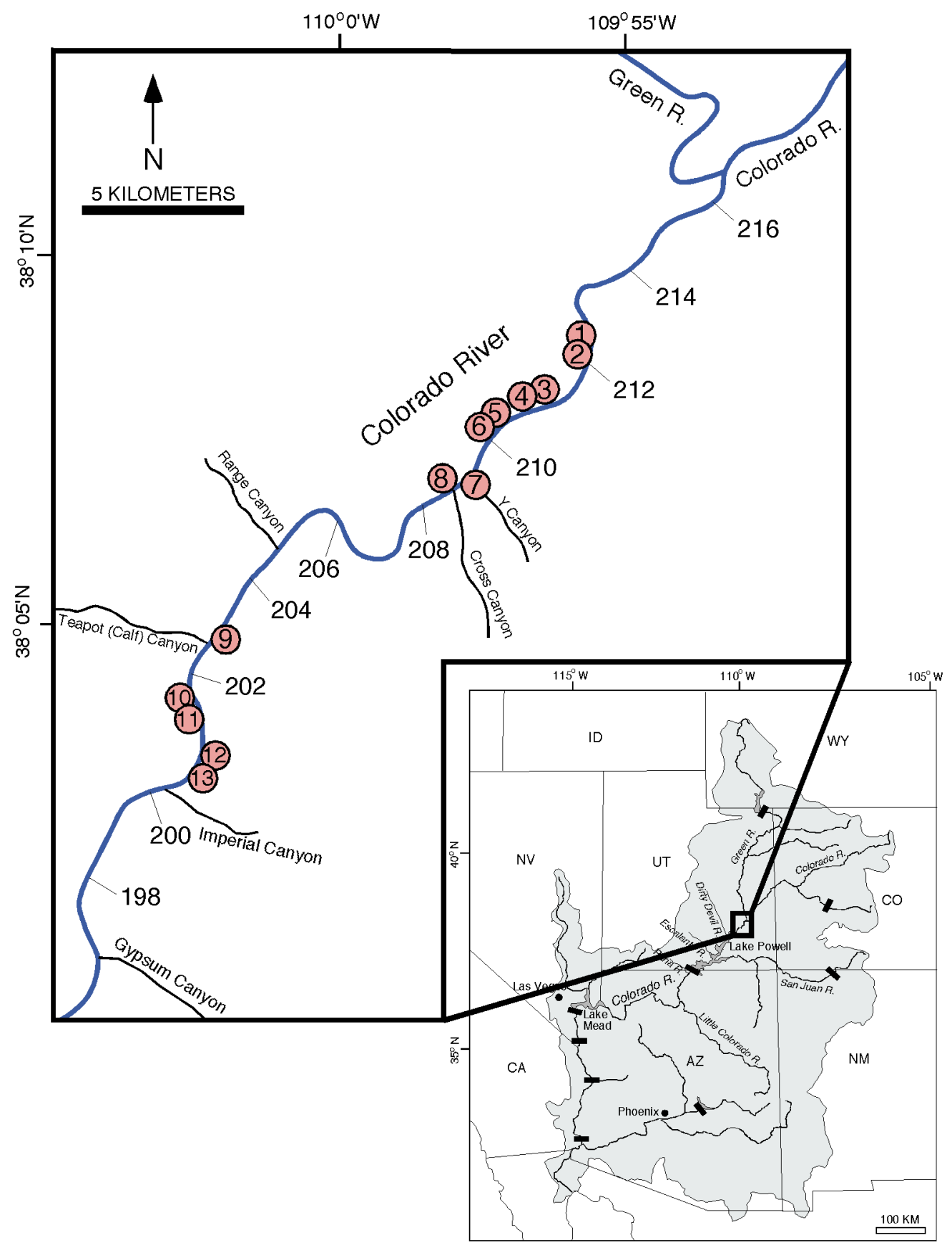

Figure 1. Study sites (numbered circles) in the Colorado River corridor through Cataract Canyon, Utah. Site descriptions are given in table 1. River miles of Belknap and others (2008) are shown. Inset map shows Cataract Canyon (box) in the context of the Colorado River basin (shaded region). Major dams of the Colorado River and its tributaries are shown as black bars on the inset map. 


\section{Project Objectives}

The objective of this field study was to measure vegetation and substrate properties in aeolian dune fields within the Colorado River corridor through Cataract Canyon, Canyonlands National Park. Vegetative cover, native and nonnative species assemblages, and substrate composition including biologic crust extent are described in this report to further the ecosystem-monitoring efforts undertaken by Canyonlands National Park. These data will also be compared, in a separate publication, with ground-cover measurements made on aeolian landscapes of the Colorado River corridor in Grand Canyon National Park, a reach of the river affected substantially by flow regulation and sedimentsupply limitations owing to Glen Canyon Dam operations.

This work in Cataract Canyon, upstream of Glen Canyon Dam and its reservoir, Lake Powell, constitutes part of a larger study of the effects of Glen Canyon Dam on the Colorado River corridor. Previous studies have shown that Glen Canyon Dam operations substantially reduced the size and number of fluvial sand deposits in Grand Canyon (Kearsley and others, 1994; Rubin and others, 2002; Wright and others, 2005; Hazel and others, 2006). Because fluvial sandbars are the primary source for sand that moves inland by wind and forms aeolian dune fields, the loss of fluvial sand, in turn, can reduce the supply of wind-blown sediment to aeolian dune fields downwind (Neal and others, 2000; Draut and Rubin, 2008; Draut and others, 2008, 2010) with possible consequences for ecosystems in those aeolian landscapes. To assess the degree to which sediment-supply limitation in Grand Canyon has affected conditions in aeolian landscapes there, it will therefore be informative to compare vegetation and substrate in aeolian dunes of Grand Canyon with those of Cataract Canyon, where hydrology and sediment supply more closely resemble natural conditions (see, for example, an earlier comparative geomorphic study by Thompson and Potochnik, 2000). 


\section{Methods}

This study focused on the Cataract Canyon reach of the Colorado River corridor in Canyonlands National Park, between the confluence of the Green and Colorado Rivers and the recent upstream extent of Lake Powell in the area of Imperial Canyon (fig. 1). Vegetation cover (percent cover and vegetation type) and substrate were measured at 13 sites during July 2010. Study sites were chosen within landscapes dominated by aeolian geomorphology, above and within $100 \mathrm{~m}$ of the highest elevation of recent fluvial sand deposition. The peak stage of the spring flood in June $2010\left(1,530 \mathrm{~m}^{3} / \mathrm{s}\right)$ was readily identifiable by the presence of driftwood, vegetation debris in wrack lines, and sandbar morphology that commonly formed separation and reattachment bars associated with eddies (Schmidt, 1990). On the basis of aeolian landforms (sand dunes, coppice dunes, and sand shadows behind rocks and vegetation), erosion, transport, and deposition by wind appeared to have been the dominant sedimentary processes recently affecting the study sites. The source of aeolian sediment at the study sites was inferred to have been a combination of new sand recently transported inland from spring flood deposits situated at lower elevation and upwind of the sites and wind reworking of sediment from older, larger flood deposits that underlie the sites (known from the presence of old driftwood logs and flood debris inland of most study sites).

Table 1 lists site numbers, names, locations, and descriptions. At Sites 1, 3, 5, and 12, ground cover appeared to be affected somewhat by camping activity, such as the presence of tent sites (Sites 1, 3, and 5) or a trail (Site 12). Sites 3 and 4 were established in the same dune field, one (Site 3) in an area affected by camp activity and the other (Site 4) apparently unaffected. Sites 5 and 6 , similarly, represent camp and noncamp areas within one dune field. Although areas affected by camping activity cannot be 
considered to have entirely natural conditions, they were included in this study in order to represent the range of ground cover in Cataract Canyon's aeolian landscapes as completely as possible.

Vegetation and substrate were measured at each site by establishing a layout of circles and linear transects referred to here as a "pod." As shown in figure 2, each pod consisted of two orthogonal transects marked out with a tape reel (one oriented upstream-to-downstream and the other oriented inland-to-riverward) and five circles outlined in the sand (one in the center of the pod and one at the end of each of the four transects). At study sites within small dune fields, the pods used transects $20 \mathrm{~m}$ long, whereas in larger dune fields the pods used transects $40 \mathrm{~m}$ long (table 1$)$. For both the smaller $(20 \times 20$ m) and larger $(40 \times 40 \mathrm{~m})$ pod size, the five circles were always the same size, having a 3-m radius (fig. 2).

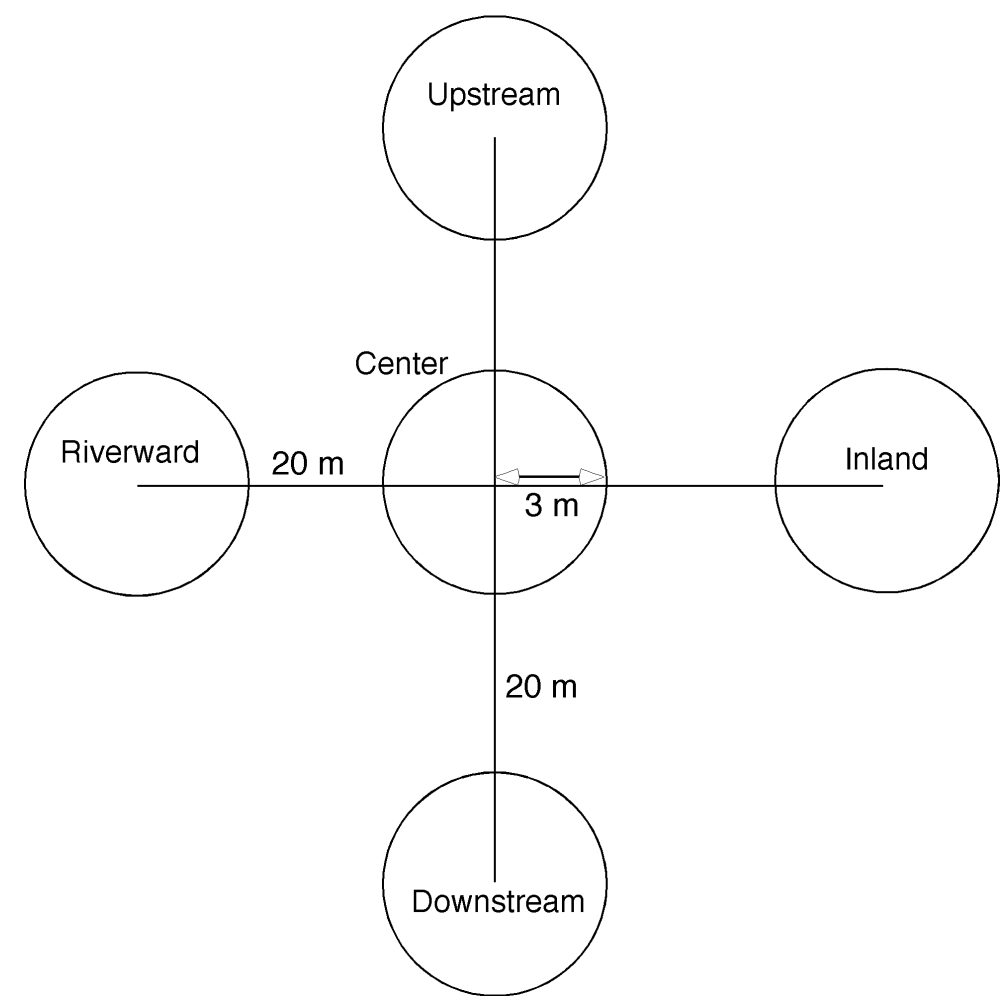

Figure 2. Scale diagram of "pod" configuration used to map vegetation and substrate in Cataract Canyon. Two transects of length $20 \mathrm{~m}$ and five circles of radius $3 \mathrm{~m}$ were used in small dune fields (as shown here). In study 
sites with larger dune fields, the pod configuration included two transects of length $40 \mathrm{~m}$ and five circles of radius $3 \mathrm{~m}$.

Along each of the transects within a pod, we measured the lengths of all gaps where the measuring tape crossed bare, open sand without rocks, biologic crust, leaf litter, or overhanging plant canopy. This method was modified from Herrick and others (2005), using their criteria to define plant canopy gaps, as a means to measure the spacing and abundance of roughness elements, vegetation, and patches of biologic crust that affect aeolian sediment mobility (Ash and Wasson, 1983; Buckley, 1987; Leys and Eldridge, 1998; Belnap, 2003; Goossens, 2004). The proportion of bare, open sand in the dune field can thus be estimated by adding all of the measured gap lengths from each transect to compile a cumulative gap length measurement and representing that total gap length as a percentage of the total transect length.

Within each of the five circles per pod, we measured the proportion of space occupied by vegetation (categorized at the species level wherever possible) and various types of substrate in which vegetation was growing. Substrate was considered in four categories: open sand, biologic soil crust, leaf litter (including driftwood, at some sites), and rock (fig. 3). We did not distinguish among the different species of biologic crust known to occur in Cataract Canyon (Webb and others, 2004). To estimate percent coverage, we compared a disc of known size with the area covered by a plant, rock, patch of soil crust, or other object of interest. The disc (radius $20 \mathrm{~cm}$ ) has an area $\left(0.13 \mathrm{~m}^{2}\right)$ approximately half of one percent of the circle size studied $\left(28.3 \mathrm{~m}^{2}\right)$. By holding a disc of known radius above plants or crust cover to gage their size and percent coverage, we avoided disturbing the ground surface unnecessarily as would happen from handling plants or placing measuring devices (such as plastic grids) directly on sensitive, soil-encrusted ground. Field sites were photographed, transect orientations were measured 
with a compass, and recent dominant wind directions were estimated by using compass measurements of dune slipface and sand-shadow orientations (table 1). All equipment was removed when the work was completed at each site.

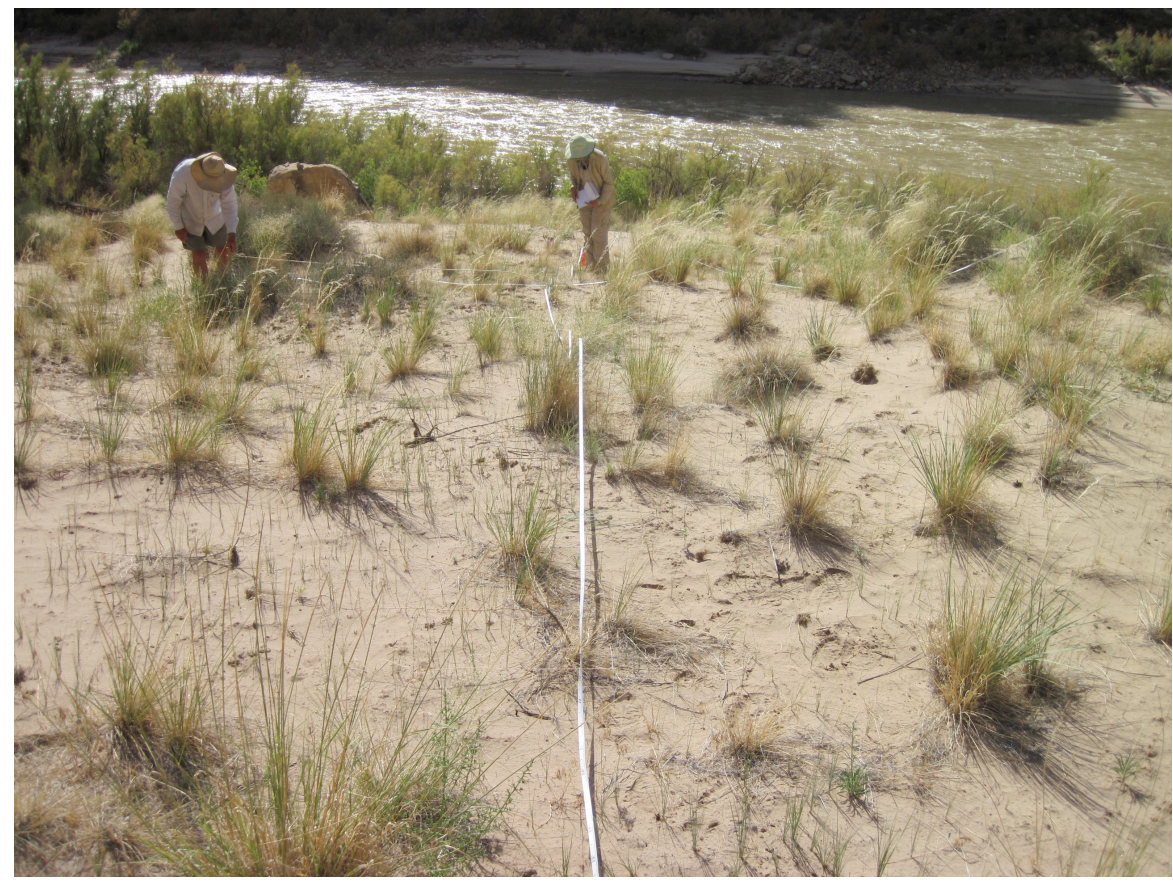

Figure 3. Measuring vegetation and substrate properties on an aeolian landscape in Cataract Canyon (Site 13), summer 2010.

\section{Results and Discussion}

Tables 2-14 list vegetation and substrate properties measured at the 13 Cataract Canyon study sites. Vegetation was identified to species level wherever possible, using names and descriptions given by Taylor (1992), Williams (2000), and Huisinga and others (2006). In cases where species 
identification was unclear, plants were identified by their family or genus, or by designation as annual or perennial grass, forb, or shrub.

Figure 4 summarizes vegetation cover. Sites where camping activity was apparent did not have substantially different vegetation coverage from study sites without camping activity (median vegetation coverage was 20.2 percent among the 4 sites with camp activity, compared with a median value of 23.1 percent for the noncamp sites and 22.4 percent for all 13 sites). The sites with camp activity had more open, bare sand than was characteristic of most noncamp study sites, judging from differences in total gap length (fig. 5). Median total gap length among the 4 sites with evidence of camp use was 78.7 percent, compared with 66.0 percent among the 9 noncamp sites and 68.8 percent for all 13 sites. Differences in the amount of open sand between sites with and without camp activity are largely attributable to differences in biologic crust coverage. As a group, the sites used as camps had less biologic crust than noncamp areas (fig. 6), with lower median values (1.53 percent for the sites with camp activity compared to 2.80 percent for sites without camp activity) and a much lower maximum extent (4.00 percent among the sites with camp activity compared to 37.4 percent among the noncamp sites; fig. 6). Notably, the site with the most biologic crust (Site 6) is only a short distance away from an area used as a camp, with the center of the Site 6 pod being $50 \mathrm{~m}$ inland of the recent spring high-water line near a large camp. Apart from one prominent trail (not near the study pod), visitor use apparently had not disturbed areas with abundant biologic soil crust a short distance away from the camp at Site 6 . Substrate composition at all 13 study sites is shown in figure 7.

Diverse vegetation assemblages were recorded at the study sites, with most aeolian landscapes containing between 10 and 20 different species. Among the native plant varieties, perennial bunchgrasses such as rice grass (Oryzopsis hymenoides, also known as genus Achnatherum or Stipa) and several species of dropseed (Sporobolus) were common, as were Ephedra shrubs, wire lettuce 
(Stephanomeria pauciflora), snakeweed (Gutierrezzia sp.), forbs such as sand verbena (Abronia elliptica), dicoria (Dicoria canescens), and globemallow (Sphaeralcea sp.), and several members of the Asteraceae/Compositae family.

Every site contained at least one nonnative plant variety within the study pod. The three nonnative plants most commonly identified were Russian thistle (tumbleweed, Salsola), brome grasses (genus Bromus; we did not distinguish among varieties such as cheat grass, ripgut brome, and brown brome), and tamarisk trees (Tamarix). Each of these is able to spread rapidly and is considered an invasive plant in southwest desert ecosystems. Salsola and Bromus are especially adept at colonizing disturbed ground surfaces (D’Antonio and Vitousek, 1992; Belnap and others, 2009). Tamarisk and brome grasses were commonly associated with one another at the Cataract Canyon study sites, with the nonnative brome growing abundantly under tamarisk trees. Nearly all tamarisk had brown leaves and many tamarisk beetles (Diorhabda elongata), which land-management agencies introduced between 2005 and 2010 in an effort to curb the spread of tamarisk. Figures 8, 9, and 10 show the total area covered by Salsola, Bromus, and Tamarix, respectively, at the study sites. There do not appear to be substantial differences among sites with camp activity and those without, though the maximum coverage of Salsola and Bromus was highest at a noncamp site (Site 6). The apparently greater coverage of tamarisk at sites with camp activity (fig. 10) is likely due to both tamarisk and human visitors preferring locations near the river. The smaller number of study sites with camp activity may make it difficult to resolve other patterns in nonnative species prevalence that might exist between camp and noncamp areas. Figure 11 illustrates the proportions of Salsola, Bromus, and Tamarix at each study site relative to all other types of vegetation. In several places those plant varieties account for a substantial proportion of the vegetation community; notably, at Sites 3, 5, and 6, invasive Salsola, Bromus, and Tamarix together make up well over half of the total vegetation (fig. 11). 


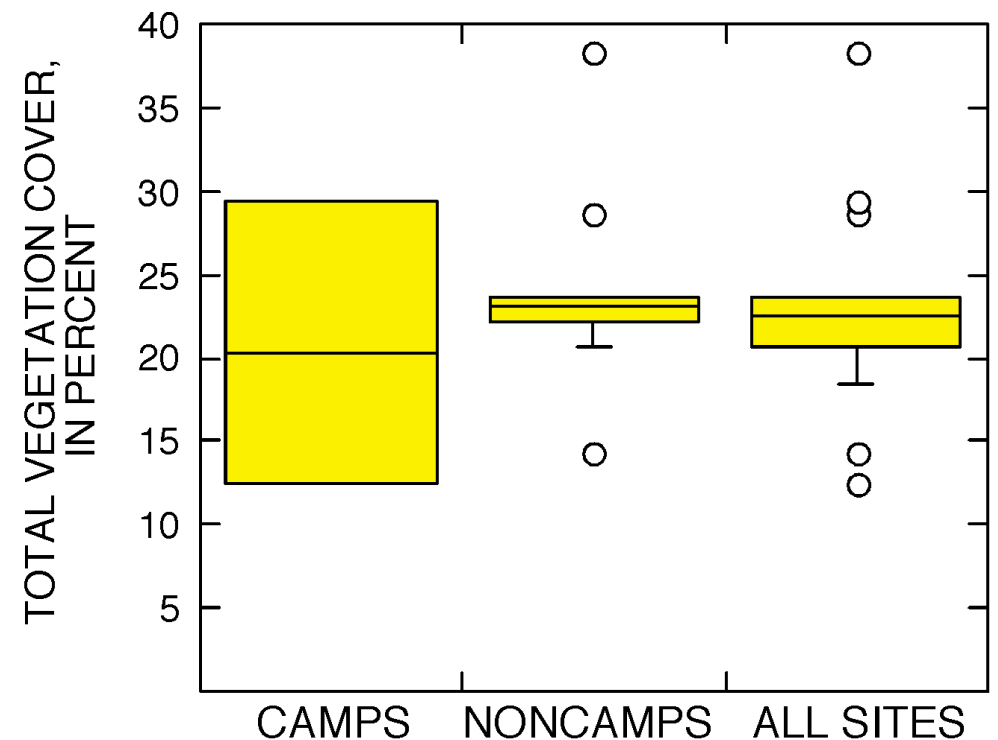

Figure 4. Box-and-whisker plots showing total area of vegetation cover, in percent, for the 4 study sites affected by camping activity (Sites 1, 3, 5, and 12), the 9 noncamp study sites, and all 13 sites combined. Length of each box spans the interquartile range (first quartile to third quartile) of the data; horizontal line through each box represents the median value. Circles mark outlier data points (those more than 1.5 times the interquartile range). Whiskers mark highest and lowest non-outlier data points. 


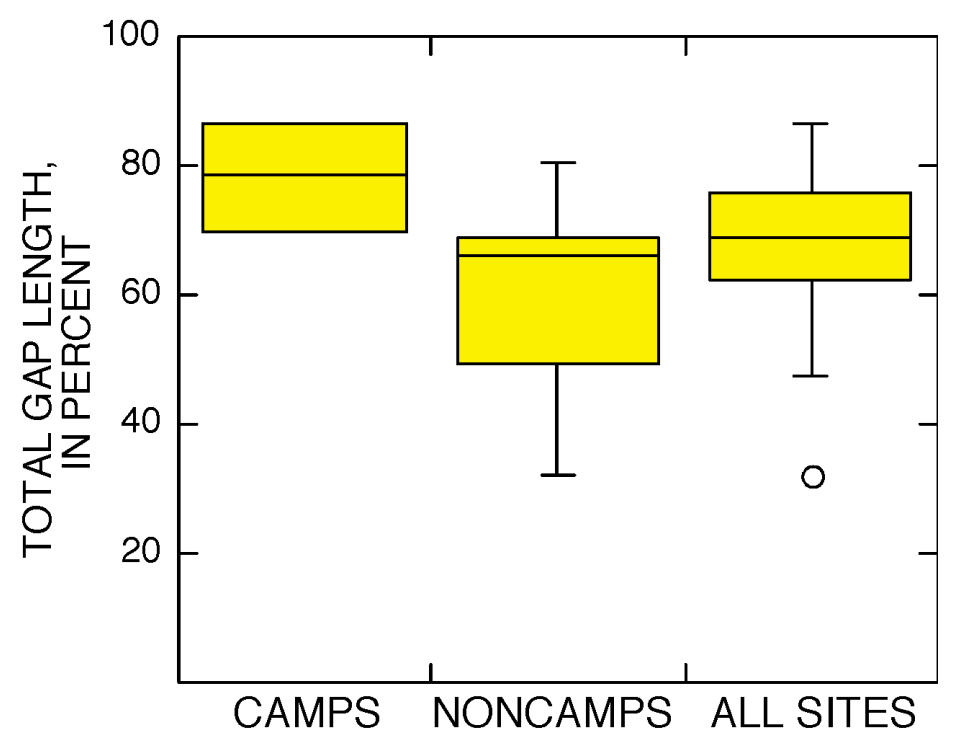

Figure 5. Box-and-whisker plots showing total gap length, as a percent of total transect length, for the 4 study sites affected by camping activity (Sites 1, 3, 5, and 12), the 9 noncamp study sites, and all 13 sites combined.

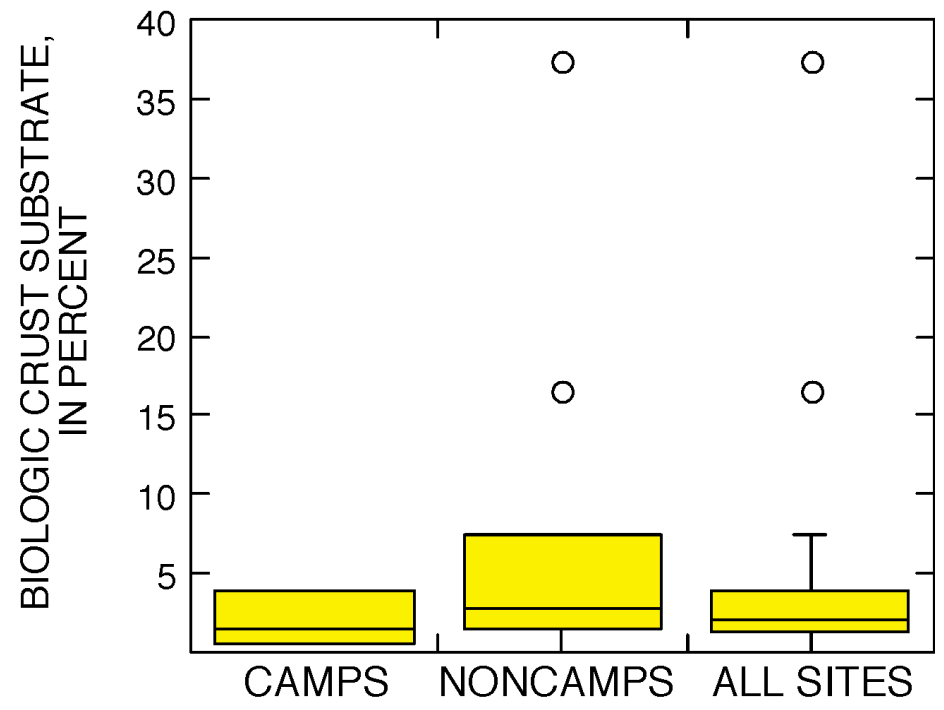

Figure 6. Box-and-whisker plots showing biologic soil crust abundance, as a percent of total substrate, for the 4 study sites affected by camping activity (Sites 1, 3, 5, and 12), the 9 noncamp study sites, and all 13 sites combined. 


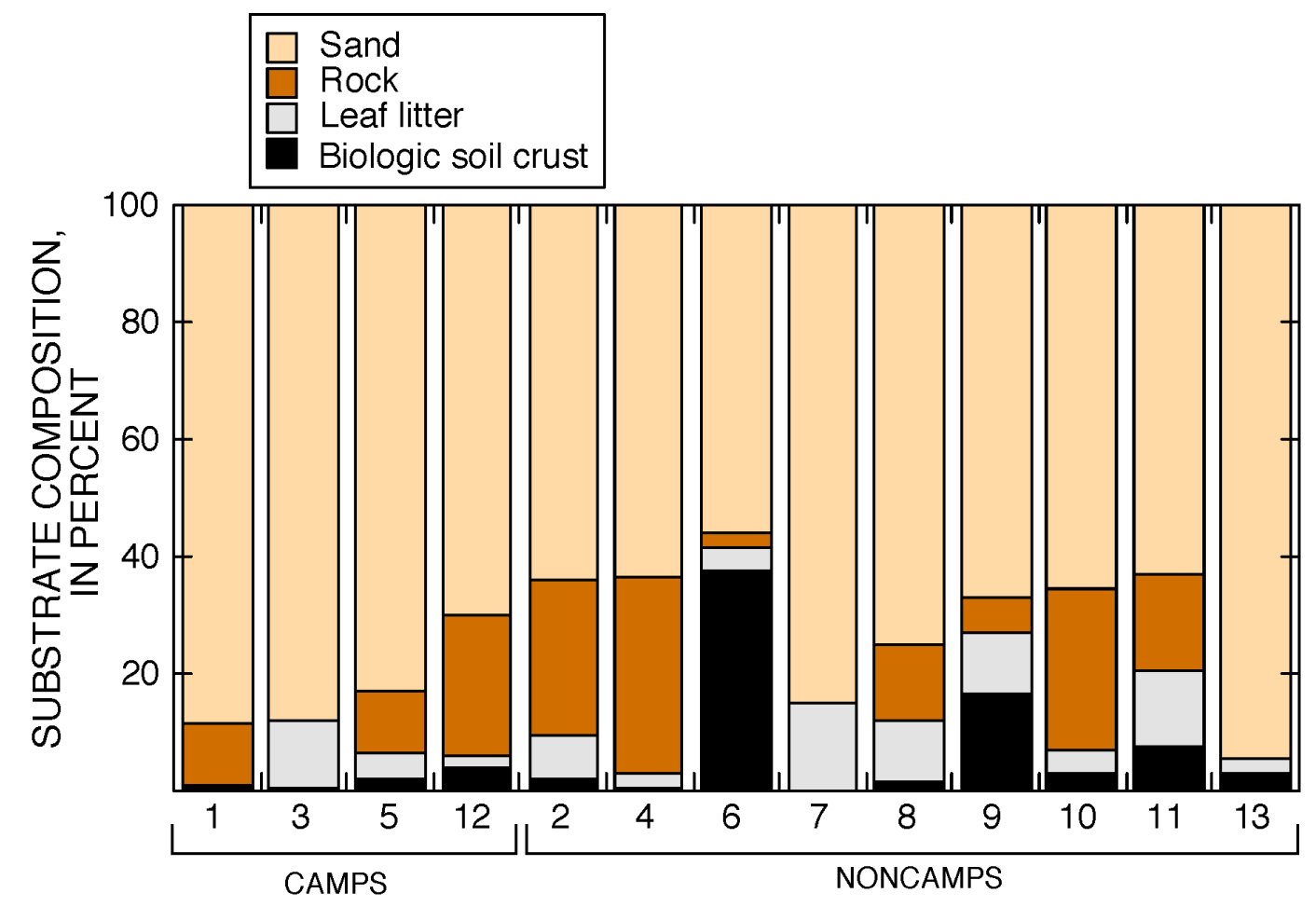

Figure 7. Substrate composition at each of the 13 study sites. Site numbers are listed below columns. 


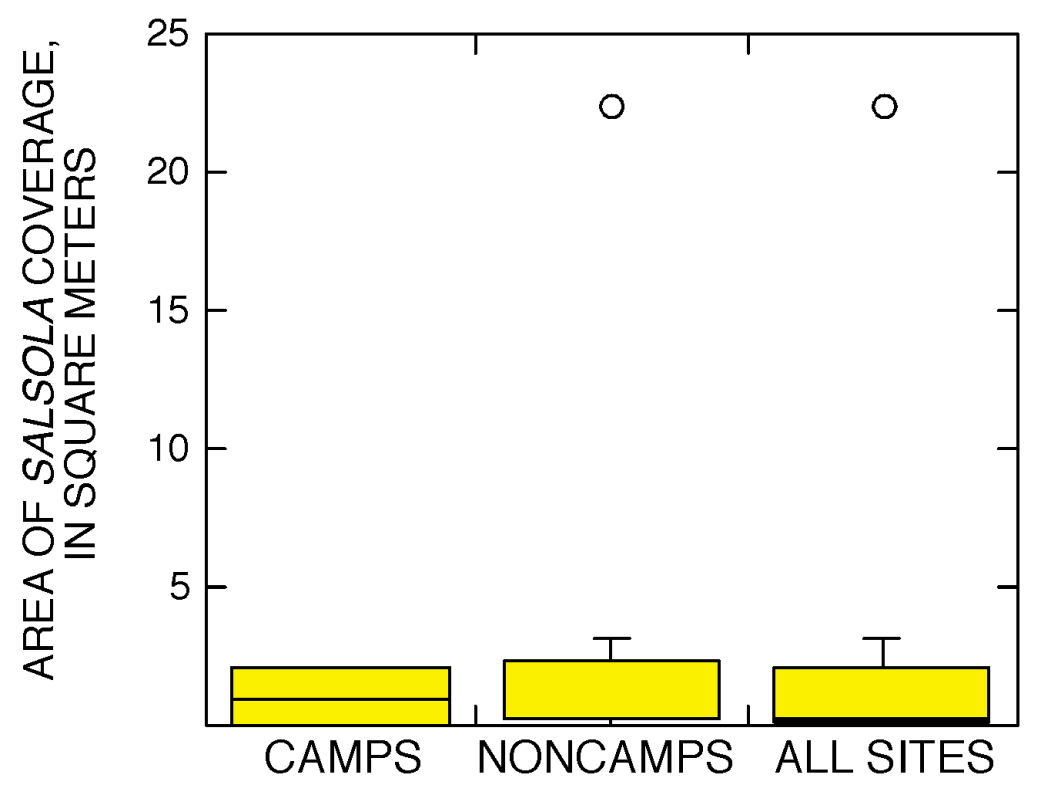

Figure 8. Box-and-whisker plots showing coverage of invasive Russian thistle (Salsola sp.) at the 4 study sites affected by camping activity (Sites 1, 3, 5, and 12), the 9 noncamp study sites, and all 13 sites combined.

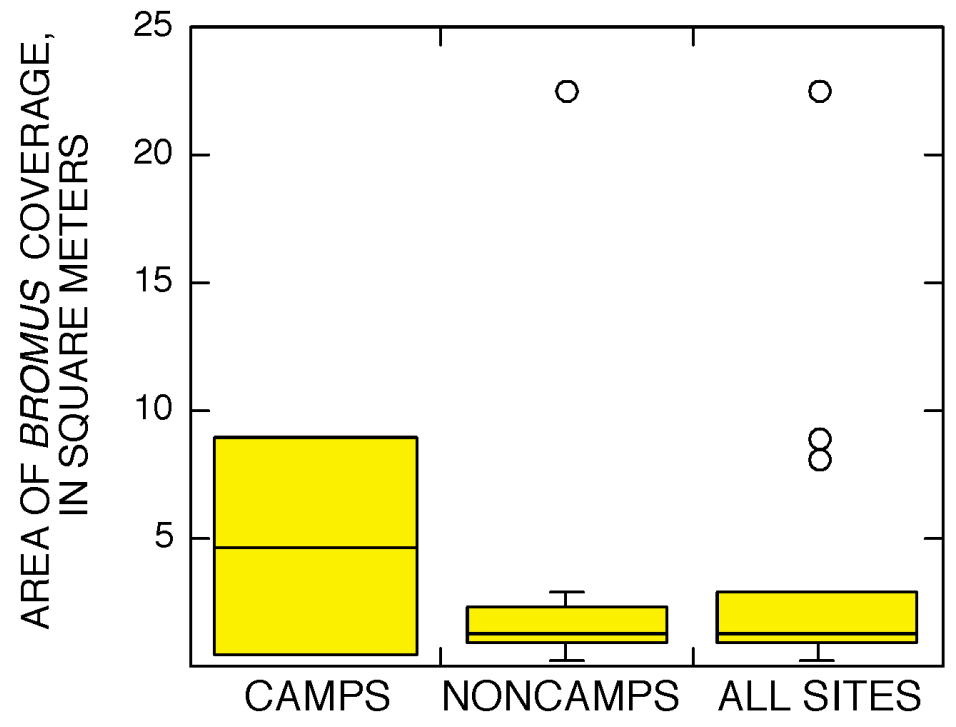

Figure 9. Box-and-whisker plots showing coverage of invasive brome grasses (Bromus sp.) at the 4 study sites affected by camping activity (Sites 1, 3, 5, and 12), the 9 noncamp study sites, and all 13 sites combined. 


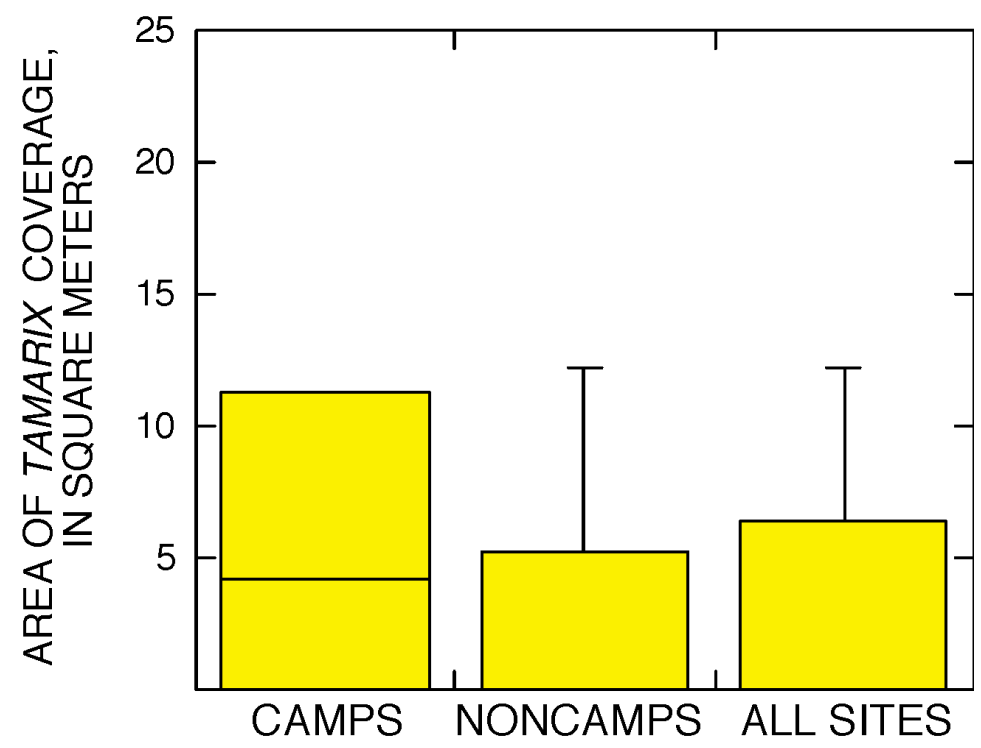

Figure 10. Box-and-whisker plots showing coverage of invasive tamarisk (Tamarix sp.) at the 4 study sites affected by camping activity (Sites 1, 3, 5, and 12), the 9 noncamp study sites, and all 13 sites combined. 


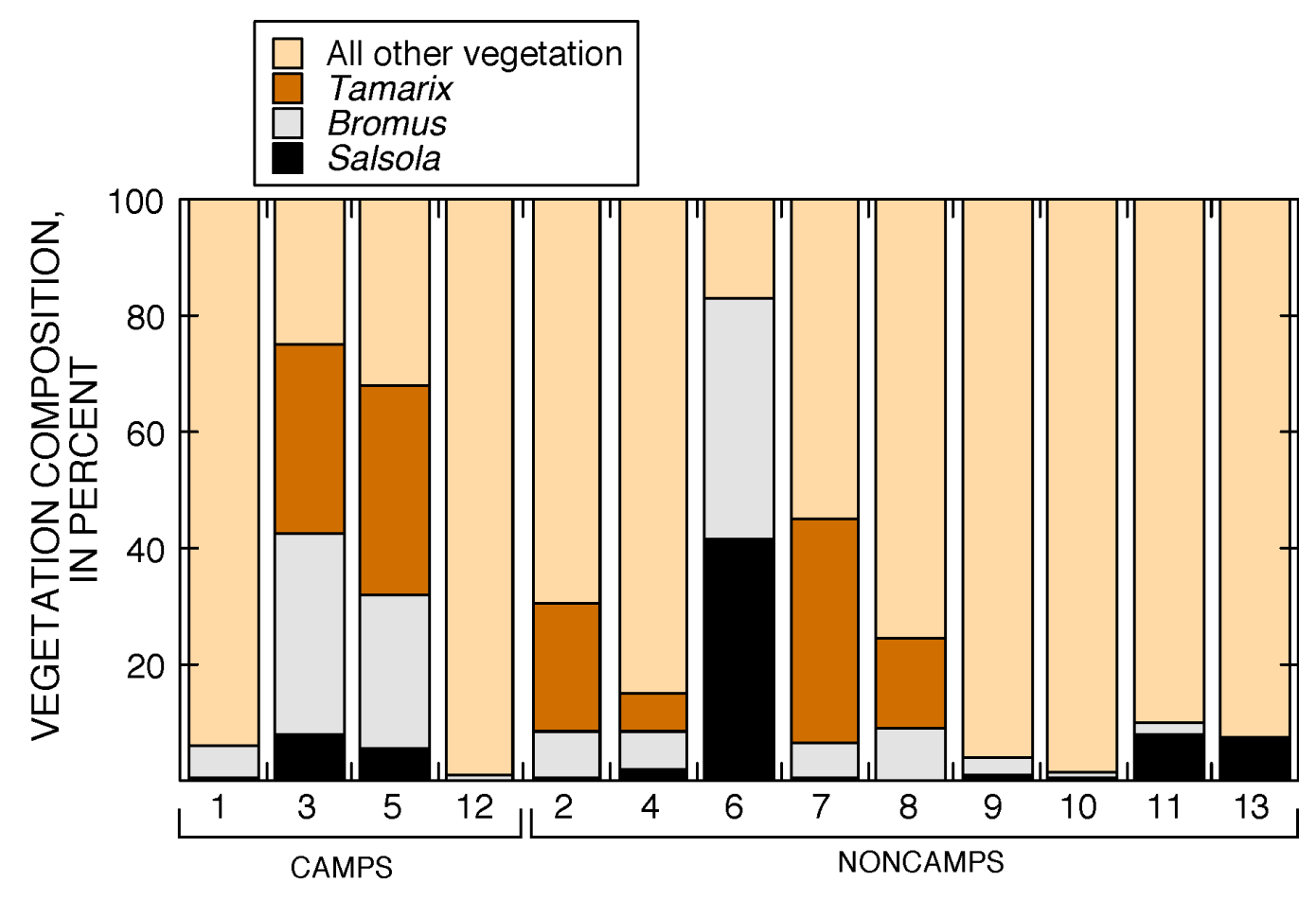

Figure 11. Vegetation composition, in percent areal coverage, at each of the 13 study sites, identifying the proportions of three prominent invasive plant types (Tamarix, Bromus, and Salsola).

\section{Conclusions}

Vegetation and substrate data presented here characterize ground cover on aeolian landscapes of the Colorado River corridor through Cataract Canyon, Utah. Some changes to the natural ecosystem likely have resulted from human camping use, notably the lower abundance of biologic soil crust and correspondingly more open, bare sand in dune fields that sustain some camp activity compared to those that do not. Nonnative vegetation was present among the plant communities at each of the 13 study sites. Invasive Salsola, Bromus, and Tamarix now compose a substantial proportion of the plant community in Cataract Canyon's aeolian landscapes. 
These data can form a basis against which to evaluate future changes in the Cataract Canyon ecosystem, the least disturbed region of the Colorado River corridor below the confluence with its largest tributary, the Green River. Upstream dams have less effect on the hydrology and sediment supply in Cataract Canyon compared to downstream reaches in Grand Canyon National Park. For this reason, comparison of these vegetation and substrate measurements with similar data from aeolian landscapes of Grand Canyon will help to resolve the effects of Glen Canyon Dam operations on the Colorado River corridor ecosystem.

\section{Acknowledgments}

This work was conducted under National Park Service Research and Collecting permit CANY2010-SCI-0003. The authors thank John Weisheit for providing logistical field support and sharing his greatly detailed knowledge of Cataract Canyon's natural and human history. R.L. Reynolds and C.D. Storlazzi provided constructive review comments that improved this report.

\section{References Cited}

Ash, J.E., and Wasson, R.J., 1983, Vegetation and sand mobility in the Australian desert dunefield: Zeitschrift für Geomorphologie, supp. v. 45, p. 7-25.

Belknap, B., Belknap, B., and Evans, L.B., 2008, Belknap's waterproof Canyonlands river guide: Evergreen, Colo., Westwater Books, 77 p., ISBN-13:978-0-916370-17-6.

Belnap, J., 2003, Biological soil crusts and wind erosion, in Belnap, J., and Lange, O.L., eds., Biological soil crusts - structure, function, and management: Berlin, Springer-Verlag, Ecological Studies series, v. 150, p. 339-347. 
Belnap, J., Reynolds, R.L., Reheis, M.C., Phillips, S.L., Urban, F.E., and Goldstein, H.L., 2009, Sediment losses and gains across a gradient of livestock grazing and plant invasion in a cool, semi-arid grassland, Colorado Plateau, USA: Aeolian Research, v. 1, p. 27-43.

Buckley, R., 1987, The effect of sparse vegetation on the transport of dune sand by wind: Nature, v. 325 , p. $426-428$.

D'Antonio, C.M., and Vitousek, P.M., 1992, Biological invasions by exotic grasses, the grass/fire cycle, and global change: Annual Review of Ecology and Systematics, v. 23, p. 63-87.

Draut, A.E., and Rubin, D.M., 2008, The role of eolian sediment in the preservation of archeologic sites along the Colorado River corridor in Grand Canyon National Park, Arizona: U.S. Geological Survey Professional Paper 1756, 71 p., accessed December 6, 2010, at http://pubs.usgs.gov/pp/1756/.

Draut, A.E., Rubin, D.M., Dierker, J.L., Fairley, H.C., Griffiths, R.E., Hazel, J.E., Jr., Hunter, R.E., Kohl, K., Leap, L.M., Nials, F.L., Topping, D.J., and Yeatts, M., 2008, Application of sedimentary-structure interpretation to geoarchaeological studies in the Colorado River corridor, Grand Canyon, Arizona, USA: Geomorphology, v. 101, no. 3, p. 497-509.

Draut, A.E., Sondossi, H.A., Dealy, T.P., Hazel, J.E., Jr., Fairley, H.C., and Brown, C.R., 2010, 2009 weather and aeolian sand-transport data from the Colorado River corridor, Grand Canyon, Arizona: U.S. Geological Survey Open-File Report 2010-1166, 98 p., accessed December 6, 2010, at http://pubs.usgs.gov/of/2010/1166/.

Goossens, D., 2004, Effect of soil crusting on the emission and transport of wind-eroded sedimentfield measurements on loamy sandy soil: Geomorphology, v. 58, p. 145-160. 
Hazel, J.E., Jr., Topping, D.J., Schmidt, J.C., and Kaplinski, M., 2006, Influence of a dam on finesediment storage in a canyon river: Journal of Geophysical Research v. 111, no. F3, doi: 10.1029/2004JF000193.

Herrick, J.E., Van Zee, J.W., Havstad, K.M., Burkett, L.M., and Whitford, W.G., 2005, Monitoring manual for grassland, shrubland, and savanna ecosystems: Las Cruces, New Mexico, U.S. Department of Agriculture, distributed by University of Arizona Press, $36 \mathrm{p}$.

Huisinga, K., Makarick, L., and Watters, K., 2006, River and desert plants of the Grand Canyon: Missoula, Montana, Mountain Press Publishing Company, 261 p.

Kearsley, L.H., Schmidt, J.C., and Warren, K.D., 1994, Effects of Glen Canyon Dam on Colorado River sand deposits used as campsites in Grand Canyon National Park, USA: Regulated Rivers, Research and Management, v. 9, p. 137-149.

Leys, J.F., and Eldridge, D.J., 1998, Influence of cryptogamic crust disturbance to wind erosion on sand and loam rangeland soils: Earth Surface Processes and Landforms, v. 23, p. 963-974.

Neal, L.A., Gilpin, D., Jonas, L., and Ballagh, J.H., 2000, Cultural resources data synthesis within the Colorado River corridor, Grand Canyon National Park and Glen Canyon National Recreation Area, Arizona: SWCA, Inc., Cultural Resources Report 98-85.

Rubin, D.M., Topping, D.J., Schmidt, J.C., Hazel, J., Kaplinski, M., and Melis, T.S., 2002, Recent sediment studies refute Glen Canyon Dam hypothesis: Eos (American Geophysical Union Transactions), v. 83, p. 273, 277-278.

Schmidt, J.C., 1990, Recirculating flow and sedimentation in the Colorado River in Grand Canyon, Arizona: Journal of Geology, v. 98, p. 709-724. 
Taylor, R.J., 1992, Sagebrush country; a wildflower sanctuary: Missoula, Montana, Mountain Press Publishing Company, 209 p.

Thompson, K.S., and Potochnik, A.R., 2000, Development of a geomorphic model to predict erosion of pre-dam Colorado River terraces containing archaeological resources: SWCA, Inc. Cultural Resources Report 99-257.

Webb, R.H., Belnap, J., and Weisheit, J.S., 2004, Cataract Canyon—a human and environmental history of the rivers in Canyonlands: University of Utah Press, 268 p.

Williams, D.B., 2000, A naturalist's guide to canyon country: Guilford, Conn., Globe Pequot Press, 188 p.

Wright, S.A., Melis, T.S., Topping, D.J., and Rubin, D.M., 2005, Influence of Glen Canyon Dam operations on downstream sand resources of the Colorado River in Grand Canyon, in Gloss, S.P., Lovich, J.E., and Melis, T.S., eds., The state of the Colorado River ecosystem in Grand Canyon: U.S. Geological Survey Circular 1282, p. 17-31. 
Table 1. Details of Cataract Canyon study sites.

[Site names refer to the name of the rapid, camp, or side canyon nearest them, and to whether the site is on the left or right side of the river when viewed facing downstream. Wind direction is interpreted to be the recent dominant direction from which the wind came, estimated by measuring azimuth orientations of dune slipfaces and sand shadows behind rocks, vegetation, or other obstacles.]

\begin{tabular}{clccccc}
\hline $\begin{array}{c}\text { Site } \\
\text { Number }\end{array}$ & \multicolumn{1}{c}{ Site Name } & Latitude & Longitude & Pod Size & $\begin{array}{c}\text { Camp } \\
\text { Activity? }\end{array}$ & $\begin{array}{c}\text { Wind } \\
\text { Direction }\end{array}$ \\
\hline \hline 1 & Brown Betty, Right & $38^{\circ} 08^{\prime} 52.43^{\prime \prime} \mathrm{N}$ & $109^{\circ} 55^{\prime} 40.38^{\prime \prime} \mathrm{W}$ & $40 \times 40 \mathrm{~m}$ & Yes & $190-220^{\circ}$ \\
2 & Lower 2, Right & $38^{\circ} 08^{\prime} 40.36^{\prime \prime} \mathrm{N}$ & $109^{\circ} 55^{\prime} 44.52^{\prime \prime} \mathrm{W}$ & $40 \times 40 \mathrm{~m}$ & No & $149-183^{\circ}$ \\
3 & Rapid 5, Right (camp pod) & $38^{\circ} 08^{\prime} 06.28^{\prime \prime} \mathrm{N}$ & $109^{\circ} 56^{\prime} 44.99^{\prime \prime} \mathrm{W}$ & $40 \times 40 \mathrm{~m}$ & Yes & $205-224^{\circ}$ \\
4 & Rapid 5, Right (noncamp pod) & $38^{\circ} 08^{\prime} 07.47^{\prime \prime} \mathrm{N}$ & $109^{\circ} 56^{\prime} 41.25^{\prime \prime} \mathrm{W}$ & $20 \times 20 \mathrm{~m}$ & No & $205-224^{\circ}$ \\
5 & Lower 5, Right (camp pod) & $38^{\circ} 07^{\prime} 56.61^{\prime \prime} \mathrm{N}$ & $109^{\circ} 57^{\prime} 08.47^{\prime \prime} \mathrm{W}$ & $40 \times 40 \mathrm{~m}$ & Yes & $200-235^{\circ}$ \\
6 & Lower 5, Right (noncamp pod) & $38^{\circ} 07^{\prime} 57.34^{\prime \prime} \mathrm{N}$ & $109^{\circ} 57^{\prime} 07.75^{\prime \prime} \mathrm{W}$ & $40 \times 40 \mathrm{~m}$ & No & $200-235^{\circ}$ \\
7 & Upper Tilted Park, Left & $38^{\circ} 06^{\prime} 46.23^{\prime \prime} \mathrm{N}$ & $109^{\circ} 57^{\prime} 53.06 " \mathrm{~W}$ & $40 \times 40 \mathrm{~m}$ & No & $265-274^{\circ}$ \\
8 & Lower Y, Right & $38^{\circ} 06^{\prime} 47.60^{\prime \prime} \mathrm{N}$ & $109^{\circ} 58^{\prime} 08.96 " \mathrm{~W}$ & $40 \times 40 \mathrm{~m}$ & No & $265-274^{\circ}$ \\
9 & Big Drop Beach, Left & $38^{\circ} 05^{\prime} 00.52^{\prime \prime} \mathrm{N}$ & $110^{\circ} 02^{\prime} 12.23^{\prime \prime} \mathrm{W}$ & $20 \times 20 \mathrm{~m}$ & No & $240-250^{\circ}$ \\
10 & Upper 25, Right & $38^{\circ} 03^{\prime} 55.84^{\prime \prime} \mathrm{N}$ & $110^{\circ} 02^{\prime} 40.53^{\prime \prime} \mathrm{W}$ & $20 \times 20 \mathrm{~m}$ & No & $101-165^{\circ}$ \\
11 & Lower 25, Right & $38^{\circ} 03^{\prime} 51.47^{\prime \prime} \mathrm{N}$ & $110^{\circ} 02^{\prime} 41.78^{\prime \prime} \mathrm{W}$ & $40 \times 40 \mathrm{~m}$ & No & $130-159^{\circ}$ \\
12 & Ten Cent Camp, Left & $38^{\circ} 03^{\prime} 22.50^{\prime \prime} \mathrm{N}$ & $110^{\circ} 02^{\prime} 33.69^{\prime \prime} \mathrm{W}$ & $20 \times 20 \mathrm{~m}$ & Yes & $175-208^{\circ}$ \\
13 & Lower Ten Cent, Left & $38^{\circ} 03^{\prime} 09.81^{\prime \prime} \mathrm{N}$ & $110^{\circ} 02^{\prime} 35.80^{\prime \prime} \mathrm{W}$ & $20 \times 20 \mathrm{~m}$ & No & $194-230^{\circ}$ \\
\hline
\end{tabular}


Table 2. Vegetation cover and substrate measured at Site 1 (Brown Betty, Right).

\begin{tabular}{|c|c|c|}
\hline Center Circle & Vegetation & Percent Cover \\
\hline & None & \\
\hline & Total & 0 \\
\hline & Substrate & Percent Cover \\
\hline & Sand & 100 \\
\hline & Rock & 0 \\
\hline & Leaf litter & 0 \\
\hline & Biologic soil crust & 0 \\
\hline Upstream Circle & Vegetation & Percent Cover \\
\hline & Netleaf hackberry (Celtis laevigata) & 17.0 \\
\hline & Snakeweed (Gutierrezzia sp.) & 3.75 \\
\hline & Broadleaf milkweed (Asclepias latifolia) & 2.00 \\
\hline & Wire lettuce (Stephanomeria pauciflora) & 1.75 \\
\hline & Rice grass (Oryzopsis hymenoides) & 1.75 \\
\hline & Unidentified legume & 1.00 \\
\hline & Unidentified annual forb & 1.00 \\
\hline & Russian thistle (Salsola sp.) & 0.13 \\
\hline & Total & 28.4 \\
\hline & Substrate & Percent Cover \\
\hline & $\overline{\text { Sand }}$ & 87.3 \\
\hline & Rock & 12.5 \\
\hline & Leaf litter & 0 \\
\hline & Biologic soil crust & 0.25 \\
\hline
\end{tabular}


Table 2. Vegetation cover and substrate measured at Site 1 (Brown Betty, Right)—Continued.

\begin{tabular}{|c|c|c|}
\hline \multirow[t]{11}{*}{ Downstream Circle } & Vegetation & Percent Cover \\
\hline & Dropseed (Sporobolus sp.) & 0.75 \\
\hline & Russian thistle (Salsola sp.) & 0.18 \\
\hline & Brome grasses (Bromus sp.) & 0.13 \\
\hline & Unidentified annual grass & 0.05 \\
\hline & Total & 1.10 \\
\hline & Substrate & Percent Cover \\
\hline & Sand & 90.9 \\
\hline & Rock & 9.00 \\
\hline & Leaf litter & 0.10 \\
\hline & Biologic soil crust & 0 \\
\hline \multirow[t]{13}{*}{ Inland Circle } & Vegetation & Percent Cover \\
\hline & Ephedra (Ephedra sp.) & 25.0 \\
\hline & Brome grasses (Bromus sp.) & 3.50 \\
\hline & Snakeweed (Gutierrezzia sp.) & 2.75 \\
\hline & Prince's plume (Stanleya pinnata) & 1.00 \\
\hline & Bladderpod (Lesquerella sp.) & 1.00 \\
\hline & Prickly pear (Opuntia sp.) & 0.10 \\
\hline & Total & 33.4 \\
\hline & Substrate & Percent Cover \\
\hline & Sand & 64.0 \\
\hline & Rock & 30.0 \\
\hline & Leaf litter & 0 \\
\hline & Biologic soil crust & 6.00 \\
\hline
\end{tabular}


Table 2. Vegetation cover and substrate measured at Site 1 (Brown Betty, Right)—Continued.

\begin{tabular}{llr}
\hline Riverward Circle & Vegetation & Percent Cover \\
\hline \hline & None & \\
& Total & 0 \\
& Percent Cover \\
\cline { 2 - 2 } & 100 \\
\hline \hline Sand & 0 \\
Rock & 0 \\
Leaf litter & 0
\end{tabular}

Total gap length on upstream/downstream transect (out of $4,000 \mathrm{~cm}$ ):

$3,283 \mathrm{~cm}$

Total gap length on inland/riverward transect (out of $4,000 \mathrm{~cm}$ ):

$3,240 \mathrm{~cm}$

Summary

Total vegetation cover, in percent

12.6

Total sand substrate, in percent

88.4

Total rock substrate, in percent

10.3

Total leaf litter substrate, in percent

0.02

Total biologic crust substrate, in percent

1.25

Total gap length, in percent

81.5 
Table 3. Vegetation cover and substrate measured at Site 2 (Lower 2, Right).

\begin{tabular}{|c|c|c|}
\hline \multirow[t]{2}{*}{ Center Circle } & \multirow{2}{*}{$\begin{array}{l}\text { Vegetation } \\
\text { Rice grass (Oryzopsis hymenoides) }\end{array}$} & Percent Cover \\
\hline & & 6.63 \\
\hline & Unidentified perennial forb & 4.50 \\
\hline & Wire lettuce (Stephanomeria pauciflora) & 2.90 \\
\hline & Baccharis (Baccharis salicifolia) & 1.00 \\
\hline & Long-leaf brickellbush (Brickellia longifolia) & 1.00 \\
\hline & Rice grass (Oryzopsis hymenoides), dead & 1.00 \\
\hline & Unidentified aster/composite & 0.25 \\
\hline & Total & 17.3 \\
\hline & Substrate & Percent Cover \\
\hline & Sand & 90.8 \\
\hline & Rock & 9.25 \\
\hline & Leaf litter & 0 \\
\hline & Biologic soil crust & 0 \\
\hline \multirow[t]{14}{*}{ Upstream Circle } & Vegetation & Percent Cover \\
\hline & "Brome grasses (Bromus sp.) & 5.00 \\
\hline & Snakeweed (Gutierrezzia sp.) & 4.50 \\
\hline & Ephedra (Ephedra sp.) & 3.00 \\
\hline & Unidentified perennial forb & 1.50 \\
\hline & Russian thistle (Salsola sp.) & 0.75 \\
\hline & Rice grass (Oryzopsis hymenoides) & 0.25 \\
\hline & Unidentified perennial grass & 0.06 \\
\hline & Total & 15.1 \\
\hline & Substrate & Percent Cover \\
\hline & Sand & 79.0 \\
\hline & Rock & 20.0 \\
\hline & Leaf litter & 1.00 \\
\hline & Biologic soil crust & 0 \\
\hline
\end{tabular}


Table 3. Vegetation cover and substrate measured at Site 2 (Lower 2, Right)-Continued.

\begin{tabular}{|c|c|c|}
\hline Downstream Circle & Vegetation & Percent Cover \\
\hline & Alfalfa (Medicago sativa) & 0.15 \\
\hline & Total & 0.15 \\
\hline & Substrate & Percent Cover \\
\hline & Sand & 53.0 \\
\hline & Rock & 47.0 \\
\hline & Leaf litter & 0 \\
\hline & Biologic soil crust & 0 \\
\hline Inland Circle & Vegetation & Percent Cover \\
\hline & Ephedra (Ephedra sp.) & 22.0 \\
\hline & Unidentified aster/composite & 5.00 \\
\hline & Snakeweed (Gutierrezzia sp.) & 2.00 \\
\hline & Brome grasses (Bromus sp.) & 1.50 \\
\hline & Bladderpod (Lesquerella sp.) & 1.25 \\
\hline & Dropseed (Sporobolus sp.) & 1.00 \\
\hline & Rice grass (Oryzopsis hymenoides) & 0.75 \\
\hline & Claret cup cactus (Echinocereus triglochidiatus) & 0.50 \\
\hline & Unidentified grass & 0.25 \\
\hline & Netleaf hackberry (Celtis laevigata) & 0.25 \\
\hline & Total & 34.5 \\
\hline & Substrate & Percent Cover \\
\hline & Sand & 35.0 \\
\hline & Rock & 40.0 \\
\hline & Leaf litter & 15.0 \\
\hline & Biologic soil crust & 10.0 \\
\hline
\end{tabular}


Table 3. Vegetation cover and substrate measured at Site 2 (Lower 2, Right)-Continued.

\begin{tabular}{|c|c|c|}
\hline Riverward Circle & Vegetation & Percent Cover \\
\hline & Tamarisk (Tamarix sp.) & 22.5 \\
\hline & Prince's plume (Stanleya pinnata) & 7.50 \\
\hline & Snakeweed (Gutierrezzia sp.) & 4.63 \\
\hline & Brome grasses (Bromus sp.) & 1.75 \\
\hline & Total & 36.4 \\
\hline & Substrate & Percent Cover \\
\hline & Sand & 61.9 \\
\hline & Rock & 16.1 \\
\hline & Leaf litter & 22.0 \\
\hline & Biologic soil crust & 0 \\
\hline \multicolumn{2}{|c|}{$\begin{array}{l}\text { Total gap length on upstream/downstream transect (out of } 4,000 \mathrm{~cm} \text { ): } \\
\text { Total gap length on inland/riverward transect (out of } 4,000 \mathrm{~cm} \text { ): }\end{array}$} & $\begin{array}{l}2,314 \mathrm{~cm} \\
1,626 \mathrm{~cm}\end{array}$ \\
\hline \multicolumn{3}{|l|}{ Summary } \\
\hline \multicolumn{2}{|c|}{ Total vegetation cover, in percent } & 20.7 \\
\hline \multicolumn{2}{|c|}{ Total sand substrate, in percent } & 63.9 \\
\hline \multicolumn{2}{|c|}{ Total rock substrate, in percent } & 26.5 \\
\hline \multicolumn{2}{|c|}{ Total leaf litter substrate, in percent } & 7.60 \\
\hline \multicolumn{2}{|c|}{ Total biologic crust substrate, in percent } & 2.00 \\
\hline \multicolumn{2}{|c|}{ Total gap length, in percent } & 49.3 \\
\hline
\end{tabular}


Table 4. Vegetation cover and substrate measured at Site 3 (Rapid 5, Right, camp pod).

\begin{tabular}{|c|c|c|}
\hline \multirow[t]{13}{*}{ Center Circle } & Vegetation & Percent Cover \\
\hline & Tamarisk (Tamarix sp.) & 18.0 \\
\hline & Russian thistle (Salsola sp.) & 2.50 \\
\hline & Rice grass (Oryzopsis hymenoides) & 2.00 \\
\hline & Sand verbena (Abronia elliptica) & 1.60 \\
\hline & Unidentified aster/composite & 0.80 \\
\hline & Brome grasses (Bromus sp.) & 0.75 \\
\hline & Total & 25.7 \\
\hline & Substrate & Percent Cover \\
\hline & Sand & 78.0 \\
\hline & Rock & 0 \\
\hline & Leaf litter & 22.0 \\
\hline & Biologic soil crust & 0 \\
\hline \multirow[t]{14}{*}{ Upstream Circle } & Vegetation & Percent Cover \\
\hline & Rice grass (Oryzopsis hymenoides) & 2.00 \\
\hline & Unidentified aster/composite & 1.50 \\
\hline & Sand verbena (Abronia elliptica) & 1.50 \\
\hline & Brome grasses (Bromus sp.) & 0.75 \\
\hline & Unidentified perennial forb, dead & 0.40 \\
\hline & Russian thistle (Salsola sp.) & 0.25 \\
\hline & Unidentified perennial forb & 0.25 \\
\hline & Total & 6.15 \\
\hline & Substrate & Percent Cover \\
\hline & Sand & 96.8 \\
\hline & Rock & 0 \\
\hline & Leaf litter & 0.50 \\
\hline & Biologic soil crust & 2.75 \\
\hline
\end{tabular}


Table 4. Vegetation cover and substrate measured at Site 3 (Rapid 5, Right, camp pod)—Continued.

\begin{tabular}{|c|c|c|}
\hline \multirow[t]{15}{*}{ Downstream Circle } & Vegetation & Percent Cover \\
\hline & Rice grass (Oryzopsis hymenoides) & 3.25 \\
\hline & Sand verbena (Abronia elliptica) & 2.25 \\
\hline & Unidentified aster/composite & 2.00 \\
\hline & Dropseed (Sporobolus sp.) & 1.50 \\
\hline & Spike dropseed (Sporobolus contractus) & 0.90 \\
\hline & Russian thistle (Salsola sp.) & 0.75 \\
\hline & Needle-and-thread (Stipa comata) & 0.75 \\
\hline & Brome grasses (Bromus sp.) & 0.15 \\
\hline & Total & 11.6 \\
\hline & Substrate & Percent Cover \\
\hline & Sand & 100 \\
\hline & Rock & 0 \\
\hline & Leaf litter & 0 \\
\hline & Biologic soil crust & 0 \\
\hline \multirow[t]{14}{*}{ Inland Circle } & Vegetation & Percent Cover \\
\hline & Brome grasses (Bromus sp.) & 30.0 \\
\hline & Tamarisk (Tamarix sp.) & 12.0 \\
\hline & Russian thistle (Salsola $\mathrm{sp}$. ) & 3.75 \\
\hline & Rice grass (Oryzopsis hymenoides) & 0.60 \\
\hline & Unidentified aster/composite & 0.50 \\
\hline & Dropseed (Sporobolus sp.) & 0.25 \\
\hline & Pale evening primrose (Oenothera pallida) & 0.05 \\
\hline & Total & 47.2 \\
\hline & Substrate & Percent Cover \\
\hline & Sand & 65.0 \\
\hline & Rock & 0 \\
\hline & Leaf litter & 35.0 \\
\hline & Biologic soil crust & 0 \\
\hline
\end{tabular}


Table 4. Vegetation cover and substrate measured at Site 3 (Rapid 5, Right, camp pod)—Continued.

\begin{tabular}{llr}
\hline Riverward Circle & Vegetation & Percent Cover \\
\hline \hline & Willow (Salix exigua) & 0.75 \\
& Total & 0.75
\end{tabular}

\begin{tabular}{lr}
\hline Substrate & Percent Cover \\
\hline \hline Sand & 100 \\
Rock & 0 \\
Leaf litter & 0 \\
Biologic soil crust & 0
\end{tabular}

Total gap length on upstream/downstream transect (out of 4,000 cm): $\quad 2,934 \mathrm{~cm}$ Total gap length on inland/riverward transect (out of $4,000 \mathrm{~cm}$ ): $\quad 2,636 \mathrm{~cm}$

\begin{tabular}{lr}
\hline Summary & \\
\hline \hline & \\
Total vegetation cover, in percent & 18.4 \\
& \\
Total sand substrate, in percent & 88.0 \\
Total rock substrate, in percent & 0 \\
Total leaf litter substrate, in percent & 11.5 \\
Total biologic crust substrate, in percent & 0.55 \\
& \\
Total gap length, in percent & 69.6 \\
\hline
\end{tabular}


Table 5. Vegetation cover and substrate measured at Site 4 (Rapid 5, Right, noncamp pod).

\begin{tabular}{|c|c|c|}
\hline \multirow[t]{2}{*}{ Center Circle } & Vegetation & Percent Cover \\
\hline & Unidentified aster/composite & 6.13 \\
\hline & Rice grass (Oryzopsis hymenoides) & 5.88 \\
\hline & Dropseed (Sporobolus sp.) & 1.00 \\
\hline & Wire lettuce (Stephanomeria pauciflora) & 0.50 \\
\hline & Unidentified forbs & 0.30 \\
\hline & Ephedra (Ephedra sp.) & 0.25 \\
\hline & Pale evening primrose (Oenothera pallida) & 0.25 \\
\hline & Russian thistle (Salsola sp.) & 0.05 \\
\hline & Milkvetch (Astralagus sp.) & 0.05 \\
\hline & Brome grasses (Bromus sp.) & 0.05 \\
\hline & Total & 14.5 \\
\hline & Substrate & Percent Cover \\
\hline & Sand & 59.0 \\
\hline & Rock & 41.0 \\
\hline & Leaf litter & 0 \\
\hline & Biologic soil crust & 0 \\
\hline Upstream Circle & Vegetation & Percent Cover \\
\hline & Unidentified aster/composite & 6.00 \\
\hline & Rice grass (Oryzopsis hymenoides) & 3.88 \\
\hline & Brome grasses (Bromus sp.) & 2.65 \\
\hline & Dropseed (Sporobolus sp.) & 1.25 \\
\hline & Long-leaf brickellbush (Brickellia longifolia) & 1.00 \\
\hline & Ephedra (Ephedra sp.) & 0.50 \\
\hline & Milkvetch (Astralagus sp.) & 0.38 \\
\hline & Wire lettuce (Stephanomeria pauciflora) & 0.38 \\
\hline & Unidentified forbs & 0.25 \\
\hline & Snakeweed (Gutierrezzia sp.) & 0.25 \\
\hline & Pale evening primrose (Oenothera pallida) & 0.05 \\
\hline & Total & 16.6 \\
\hline & Substrate & Percent Cover \\
\hline & Sand & 47.0 \\
\hline & Rock & 52.0 \\
\hline & Leaf litter & 0 \\
\hline & Biologic soil crust & 1.00 \\
\hline
\end{tabular}


Table 5. Vegetation cover and substrate measured at Site 4 (Rapid 5, Right, noncamp pod)—Continued.

\begin{tabular}{llr}
\hline Downstream Circle & Vegetation & Percent Cover \\
\hline \hline & Tamarisk (Tamarix sp.) & 5.00 \\
& Dropseed (Sporobolus sp.) & 2.50 \\
& Rice grass (Oryzopsis hymenoides) & 2.00 \\
& Unidentified legume & 1.20 \\
& Brome grasses (Bromus sp.) & 1.00 \\
& Globemallow (Sphaeralcea sp.) & 0.80 \\
Russian thistle (Salsola sp.) & 0.75 \\
Grama grass (Bouteloua sp.) & 0.50 \\
Pale evening primrose (Oenothera pallida) & 0.15 \\
Unidentified forb & 0.10 \\
& \\
& Total & 14.0 \\
& \\
\cline { 2 - 2 } & Percent Cover \\
\hline \hline Sand & 67.5 \\
Rock & 20.0 \\
Leaf litter & 12.0 \\
Biologic soil crust & 0.50
\end{tabular}


Table 5. Vegetation cover and substrate measured at Site 4 (Rapid 5, Right, noncamp pod)—Continued.

\begin{tabular}{llr}
\hline Inland Circle & Vegetation & Percent Cover \\
\hline \hline & Rice grass (Oryzopsis hymenoides) & 3.13 \\
Unidentified aster/composite & 2.75 \\
Snakeweed (Gutierrezzia sp.) & 2.75 \\
Wire lettuce (Stephanomeria pauciflora) & 2.25 \\
Dropseed (Sporobolus sp.) & 1.00 \\
Unidentified forb & 1.00 \\
Brome grasses (Bromus sp.) & 0.75 \\
Long-leaf brickellbush (Brickellia longifolia) & 0.50 \\
Pale evening primrose (Oenothera pallida) & 0.38 \\
Sand verbena (Abronia elliptica) & 0.35 \\
Unidentified perennial grass, dead & 0.25 \\
Milkvetch (Astralagus sp.) & 0.05 \\
& \\
Total & 15.2 \\
& \\
\cline { 2 - 2 } & Percent Cover \\
\hline \hline Sand & 55.3 \\
Rock & 42.5 \\
Leaf litter & 0 \\
Biologic soil crust & 2.25
\end{tabular}


Table 5. Vegetation cover and substrate measured at Site 4 (Rapid 5, Right, noncamp pod)—Continued.

\begin{tabular}{|c|c|c|}
\hline Riverward Circle & Vegetation & Percent Cover \\
\hline & Unidentified annual grass & 5.13 \\
\hline & Pale evening primrose (Oenothera pallida) & 2.15 \\
\hline & Dropseed (Sporobolus sp.) & 2.13 \\
\hline & Rice grass (Oryzopsis hymenoides) & 1.60 \\
\hline & Russian thistle (Salsola sp.) & 0.63 \\
\hline & Unidentified forb & 0.18 \\
\hline & Brome grasses (Bromus sp.) & 0.13 \\
\hline & Total & 11.9 \\
\hline & Substrate & Percent Cover \\
\hline & Sand & 89.5 \\
\hline & Rock & 10.5 \\
\hline & Leaf litter & 0 \\
\hline & Biologic soil crust & 0 \\
\hline \multirow{2}{*}{\multicolumn{2}{|c|}{$\begin{array}{l}\text { Total gap length on upstream/downstream transect (out of 2,000 cm): } \\
\text { Total gap length on inland/riverward transect (out of 2,000 cm): }\end{array}$}} & $1,062 \mathrm{~cm}$ \\
\hline & & $1,439 \mathrm{~cm}$ \\
\hline
\end{tabular}

$\begin{array}{ll}\text { Total vegetation cover, in percent } & 14.4\end{array}$

$\begin{array}{ll}\text { Total sand substrate, in percent } & 63.7\end{array}$

Total rock substrate, in percent $\quad 33.2$

$\begin{array}{lr}\text { Total leaf litter substrate, in percent } & 2.40\end{array}$

$\begin{array}{ll}\text { Total biologic crust substrate, in percent } & 0.75\end{array}$

\begin{tabular}{lr} 
Total gap length, in percent & 62.5 \\
\hline
\end{tabular} 
Table 6. Vegetation cover and substrate measured at Site 5 (Lower 5, Right, camp pod).

\begin{tabular}{|c|c|c|}
\hline Center Circle & Vegetation & Percent Cover \\
\hline & Dicoria (Dicoria canescens) & 9.00 \\
\hline & Russian thistle (Salsola sp.) & 4.13 \\
\hline & Sand verbena (Abronia elliptica) & 3.50 \\
\hline & Rice grass (Oryzopsis hymenoides) & 2.00 \\
\hline & Dropseed (Sporobolus sp.) & 0.50 \\
\hline & Total & 19.1 \\
\hline & Substrate & Percent Cover \\
\hline & Sand & 97.0 \\
\hline & Rock & 0 \\
\hline & Leaf litter & 3.00 \\
\hline & Biologic soil crust & 0 \\
\hline Upstream Circle & Vegetation & Percent Cover \\
\hline & Tamarisk (Tamarix sp.) & 25.0 \\
\hline & Brome grasses (Bromus sp.) & 20.0 \\
\hline & Russian thistle (Salsola sp.) & 1.50 \\
\hline & Sand verbena (Abronia elliptica) & 1.00 \\
\hline & Rice grass (Oryzopsis hymenoides) & 1.00 \\
\hline & Unidentified aster/composite & 0.75 \\
\hline & Unidentified perennial grass & 0.50 \\
\hline & Needle-and-thread (Stipa comata) & 0.50 \\
\hline & Dicoria (Dicoria canescens) & 0.10 \\
\hline & Total & 50.4 \\
\hline & Substrate & Percent Cover \\
\hline & Sand & 76.5 \\
\hline & Rock & 2.50 \\
\hline & Leaf litter & 21.0 \\
\hline & Biologic soil crust & 0 \\
\hline
\end{tabular}


Table 6. Vegetation cover and substrate measured at Site 5 (Lower 5, Right, camp pod)—Continued.

\begin{tabular}{|c|c|c|}
\hline \multirow[t]{12}{*}{ Downstream Circle } & Vegetation & Percent Cover \\
\hline & Rice grass (Oryzopsis hymenoides) & 1.13 \\
\hline & Netleaf hackberry (Celtis laevigata) & 1.00 \\
\hline & Russian thistle (Salsola sp.) & 0.50 \\
\hline & Unidentified perennial grass & 0.50 \\
\hline & Unidentified forb & 0.18 \\
\hline & Total & 3.30 \\
\hline & Substrate & Percent Cover \\
\hline & Sand & 65.0 \\
\hline & Rock & 35.0 \\
\hline & Leaf litter & 0 \\
\hline & Biologic soil crust & 0 \\
\hline \multirow[t]{18}{*}{ Inland Circle } & Vegetation & Percent Cover \\
\hline & Brome grasses (Bromus sp.) & 9.00 \\
\hline & Netleaf hackberry (Celtis laevigata) & 2.75 \\
\hline & Dropseed (Sporobolus sp.) & 2.50 \\
\hline & Wire lettuce (Stephanomeria pauciflora) & 1.90 \\
\hline & Desert trumpet (Eriogonum inflatum) & 1.50 \\
\hline & Globemallow (Sphaeralcea sp.) & 1.25 \\
\hline & Rice grass (Oryzopsis hymenoides) & 1.00 \\
\hline & Snakeweed (Gutierrezzia sp.) & 0.90 \\
\hline & Unidentified aster/composite & 0.10 \\
\hline & Russian thistle (Salsola sp.) & 0.10 \\
\hline & Sand verbena (Abronia elliptica) & 0.10 \\
\hline & Total & 21.1 \\
\hline & Substrate & Percent Cover \\
\hline & Sand & 78.0 \\
\hline & Rock & 13.0 \\
\hline & Leaf litter & 0 \\
\hline & Biologic soil crust & 9.00 \\
\hline
\end{tabular}


Table 6. Vegetation cover and substrate measured at Site 5 (Lower 5, Right, camp pod)—Continued.

\begin{tabular}{llr}
\hline Riverward Circle & Vegetation & Percent Cover \\
\hline \hline & Tamarisk (Tamarix sp.) & 15.0 \\
& Unidentified forb & 1.00 \\
& Willow (Salix exigua) & 0.50 \\
& Total & 16.5 \\
& Substrate & Percent Cover \\
\hline \hline Sand & 99.5 \\
Rock & 0 \\
Leaf litter & 0.50 \\
Biologic soil crust & 0
\end{tabular}

Total gap length on upstream/downstream transect (out of 4,000 cm): $\quad 3,488 \mathrm{~cm}$ Total gap length on inland/riverward transect (out of 4,000 cm): $\quad 3,447 \mathrm{~cm}$

Summary

Total vegetation cover, in percent

Total sand substrate, in percent $\quad 83.2$

$\begin{array}{ll}\text { Total rock substrate, in percent } & 10.1\end{array}$

Total leaf litter substrate, in percent $\quad 4.90$

Total biologic crust substrate, in percent $\quad 1.80$

\begin{tabular}{lr} 
Total gap length, in percent & 86.7 \\
\hline
\end{tabular} 
Table 7. Vegetation cover and substrate measured at Site 6 (Lower 5, Right, noncamp pod).

\begin{tabular}{|c|c|c|}
\hline Center Circle & Vegetation & Percent Cover \\
\hline & "Brome grasses (Bromus sp.) & 60.0 \\
\hline & Russian thistle (Salsola sp.) & 7.00 \\
\hline & Unidentified aster/composite & 1.00 \\
\hline & Unidentified perennial forb & 1.00 \\
\hline & Needle-and-thread (Stipa comata) & 1.00 \\
\hline & Total & 70.0 \\
\hline & Substrate & Percent Cover \\
\hline & $\overline{\text { Sand }}$ & 23.6 \\
\hline & Rock & 0.88 \\
\hline & Leaf litter & 10.5 \\
\hline & Biologic soil crust & 65.0 \\
\hline Upstream Circle & Vegetation & Percent Cover \\
\hline & Russian thistle (Salsola sp.) & 6.50 \\
\hline & Brome grasses (Bromus sp.) & 5.50 \\
\hline & $\begin{array}{l}\text { Unidentified perennial grass } \\
\text { Dropseed (Sporobolus } \mathrm{sp} \text {.) }\end{array}$ & $\begin{array}{l}4.50 \\
3.50\end{array}$ \\
\hline & Unidentified perennial forb & 1.70 \\
\hline & Unidentified aster/composite & 1.00 \\
\hline & Sand verbena (Abronia elliptica) & 1.00 \\
\hline & Total & 23.7 \\
\hline & Substrate & Percent Cover \\
\hline & Sand & 87.0 \\
\hline & Rock & 0 \\
\hline & Leaf litter & 6.00 \\
\hline & Biologic soil crust & 7.00 \\
\hline
\end{tabular}


Table 7. Vegetation cover and substrate measured at Site 6 (Lower 5, Right, noncamp pod)—Continued.

\begin{tabular}{|c|c|c|}
\hline \multirow[t]{16}{*}{ Downstream Circle } & Vegetation & Percent Cover \\
\hline & Russian thistle (Salsola sp.) & 4.50 \\
\hline & Spike dropseed (Sporobolus contractus) & 3.00 \\
\hline & Unidentified aster/composite & 2.00 \\
\hline & Brome grasses (Bromus sp.) & 1.75 \\
\hline & Sand verbena (Abronia elliptica) & 1.75 \\
\hline & Dropseed (Sporobolus sp.) & 1.10 \\
\hline & Pale evening primrose (Oenothera pallida) & 0.75 \\
\hline & Dicoria (Dicoria canescens) & 0.75 \\
\hline & Unidentified perennial grass & 0.50 \\
\hline & Total & 16.1 \\
\hline & Substrate & Percent Cover \\
\hline & Sand & 99.9 \\
\hline & Rock & 0.10 \\
\hline & Leaf litter & 0 \\
\hline & Biologic soil crust & 0 \\
\hline \multirow[t]{11}{*}{ Inland Circle } & Vegetation & Percent Cover \\
\hline & Russian thistle (Salsola sp.) & 16.5 \\
\hline & Brome grasses (Bromus sp.) & 2.50 \\
\hline & Dropseed (Sporobolus sp.) & 1.00 \\
\hline & Unidentified aster/composite & 0.50 \\
\hline & Total & 20.5 \\
\hline & Substrate & Percent Cover \\
\hline & Sand & 20.0 \\
\hline & Rock & 10.0 \\
\hline & Leaf litter & 0 \\
\hline & Biologic soil crust & 70.0 \\
\hline
\end{tabular}


Table 7. Vegetation cover and substrate measured at Site 6 (Lower 5, Right, noncamp pod)—Continued.

\begin{tabular}{llr}
\hline Riverward Circle & Vegetation & Percent Cover \\
\hline \hline & Russian thistle (Salsola sp.) & 45.0 \\
& Brome grasses (Bromus sp.) & 10.0 \\
& Unidentified aster/composite & 2.50 \\
& Unidentified perennial grass & 2.00 \\
& Dropseed (Sporobolus sp.) & 1.00 \\
& Needle-and-thread (Stipa comata) & 1.00 \\
& Unidentified forb & 0.10 \\
& Total & \\
& & 61.6 \\
\cline { 2 - 3 } & Substrate & 48.5 \\
& Sand & 1.50 \\
& Rock & 5.00 \\
& Leaf litter & 45.0 \\
Biologic soil crust & \\
& & $1,799 \mathrm{~cm}$ \\
Total gap length on upstream/downstream transect (out of 4,000 cm): & $782 \mathrm{~cm}$ \\
Total gap length on inland/riverward transect (out of $4,000 \mathrm{~cm}):$ & \\
\hline Summary & \\
\hline \hline
\end{tabular}

Total vegetation cover, in percent $\quad 38.4$

$\begin{array}{lr}\text { Total sand substrate, in percent } & 55.8\end{array}$

Total rock substrate, in percent $\quad 2.50$

Total leaf litter substrate, in percent $\quad 4.30$

$\begin{array}{ll}\text { Total biologic crust substrate, in percent } & 37.4\end{array}$

\begin{tabular}{lr} 
Total gap length, in percent & 32.3 \\
\hline
\end{tabular} 
Table 8. Vegetation cover and substrate measured at Site 7 (Upper Tilted Park, Left).

\begin{tabular}{|c|c|c|}
\hline Center Circle & Vegetation & Percent Cover \\
\hline & Rice grass (Oryzopsis hymenoides) & 12.5 \\
\hline & Inland saltgrass (Distichlis spicata) & 3.25 \\
\hline & Unidentified aster/composite & 1.25 \\
\hline & Unidentified aster/composite, dead & 1.00 \\
\hline & Total & 18.0 \\
\hline & Substrate & Percent Cover \\
\hline & Sand & 98.0 \\
\hline & Rock & 0 \\
\hline & Leaf litter & 2.00 \\
\hline & Biologic soil crust & 0 \\
\hline Upstream Circle & Vegetation & Percent Cover \\
\hline & Sand verbena (Abronia elliptica) & 4.25 \\
\hline & Tamarisk (Tamarix sp.) & 3.00 \\
\hline & Rice grass (Oryzopsis hymenoides) & 2.25 \\
\hline & Unidentified forb & 2.06 \\
\hline & Brome grasses (Bromus sp.) & 1.50 \\
\hline & Inland saltgrass (Distichlis spicata) & 0.25 \\
\hline & Total & 13.3 \\
\hline & Substrate & Percent Cover \\
\hline & Sand & 91.3 \\
\hline & Rock & 0 \\
\hline & Leaf litter & 8.75 \\
\hline & Biologic soil crust & 0 \\
\hline
\end{tabular}


Table 8. Vegetation cover and substrate measured at Site 7 (Upper Tilted Park, Left)—Continued.

\begin{tabular}{|c|c|c|}
\hline \multirow[t]{12}{*}{ Downstream Circle } & Vegetation & Percent Cover \\
\hline & Tamarisk (Tamarix sp.) & 20.0 \\
\hline & Inland saltgrass (Distichlis spicata) & 11.8 \\
\hline & Unidentified forb & 3.30 \\
\hline & Rice grass (Oryzopsis hymenoides) & 0.50 \\
\hline & Russian thistle (Salsola sp.) & 0.50 \\
\hline & Total & 36.1 \\
\hline & Substrate & Percent Cover \\
\hline & Sand & 97.3 \\
\hline & Rock & 0 \\
\hline & Leaf litter & 2.75 \\
\hline & Biologic soil crust & 0 \\
\hline \multirow[t]{12}{*}{ Inland Circle } & Vegetation & Percent Cover \\
\hline & Tamarisk (Tamarix sp.) & 20.0 \\
\hline & Inland saltgrass (Distichlis spicata) & 8.00 \\
\hline & Brome grasses (Bromus sp.) & 5.00 \\
\hline & Spike dropseed (Sporobolus contractus) & 3.50 \\
\hline & Unidentified aster/composite & 0.20 \\
\hline & Total & 36.7 \\
\hline & Substrate & Percent Cover \\
\hline & Sand & 40.0 \\
\hline & Rock & 0 \\
\hline & Leaf litter & 60.0 \\
\hline & Biologic soil crust & 0 \\
\hline
\end{tabular}


Table 8. Vegetation cover and substrate measured at Site 7 (Upper Tilted Park, Left)—Continued.

\begin{tabular}{llr}
\hline Riverward Circle & Vegetation & Percent Cover \\
\hline \hline & Willow (Salix exigua) & 6.50 \\
& Total & 6.50 \\
& Substrate & Percent Cover \\
\hline \hline Sand & 98.8 \\
Rock & 0 \\
Leaf litter & 1.25 \\
Biologic soil crust & 0
\end{tabular}

Total gap length on upstream/downstream transect (out of 4,000 cm):

$3,469 \mathrm{~cm}$

Total gap length on inland/riverward transect (out of $4,000 \mathrm{~cm}$ ):

$2,226 \mathrm{~cm}$

Summary

Total vegetation cover, in percent

Total sand substrate, in percent

85.1

Total rock substrate, in percent

0

Total leaf litter substrate, in percent

15.0

Total biologic crust substrate, in percent 
Table 9. Vegetation cover and substrate measured at Site 8 (Lower Y, Right).

\begin{tabular}{|c|c|c|}
\hline \multirow[t]{2}{*}{ Center Circle } & \multirow{2}{*}{$\begin{array}{l}\text { Vegetation } \\
\text { Willow (Salix exigua) }\end{array}$} & Percent Cover \\
\hline & & 10.0 \\
\hline & Brome grasses (Bromus sp.) & 6.50 \\
\hline & Snakeweed (Gutierrezzia sp.) & 4.25 \\
\hline & Unidentified perennial grass & 4.00 \\
\hline & Rice grass (Oryzopsis hymenoides) & 1.75 \\
\hline & Unidentified aster/composite & 1.58 \\
\hline & Dropseed (Sporobolus sp.) & 0.50 \\
\hline & Unidentified forb & 0.10 \\
\hline & Total & 26.5 \\
\hline & Substrate & Percent Cover \\
\hline & Sand & 90.3 \\
\hline & Rock & 1.00 \\
\hline & Leaf litter & 8.75 \\
\hline & Biologic soil crust & 0 \\
\hline Upstream Circle & Vegetation & Percent Cover \\
\hline & U Unidentified perennial grass & 10.0 \\
\hline & Rice grass (Oryzopsis hymenoides) & 4.50 \\
\hline & Tamarisk (Tamarix sp.) & 3.50 \\
\hline & Dropseed (Sporobolus sp.) & 2.00 \\
\hline & Cottonwood (Populus sp.), dead & 1.50 \\
\hline & Unidentified aster/composite & 0.25 \\
\hline & Total & 21.8 \\
\hline & Substrate & Percent Cover \\
\hline & Sand & 86.5 \\
\hline & Rock & 0 \\
\hline & Leaf litter & 13.5 \\
\hline & Biologic soil crust & 0 \\
\hline
\end{tabular}


Table 9. Vegetation cover and substrate measured at Site 8 (Lower Y, Right)—Continued.

\begin{tabular}{|c|c|c|}
\hline \multirow[t]{14}{*}{ Downstream Circle } & Vegetation & Percent Cover \\
\hline & Snakeweed (Gutierrezzia sp.) & 5.50 \\
\hline & Brome grasses (Bromus sp.) & 2.50 \\
\hline & Unidentified perennial grass, dead & 2.00 \\
\hline & Wire lettuce (Stephanomeria pauciflora) & 1.75 \\
\hline & Unidentified aster/composite & 1.00 \\
\hline & Willow (Salix exigua) & 0.20 \\
\hline & Unidentified perennial grass & 0.10 \\
\hline & Total & 13.1 \\
\hline & Substrate & Percent Cover \\
\hline & Sand & 68.5 \\
\hline & Rock & 30.0 \\
\hline & Leaf litter & 1.00 \\
\hline & Biologic soil crust & 0.50 \\
\hline \multirow[t]{14}{*}{ Inland Circle } & Vegetation & Percent Cover \\
\hline & Tamarisk (Tamarix sp.) & 10 \\
\hline & Unidentified perennial grasses & 7.50 \\
\hline & Sand verbena (Abronia elliptica) & 5.50 \\
\hline & Saltbush (Atriplex sp.) & 4.50 \\
\hline & Rice grass (Oryzopsis hymenoides) & 2.25 \\
\hline & Brome grasses (Bromus sp.) & 1.50 \\
\hline & Wire lettuce (Stephanomeria pauciflora) & 0.70 \\
\hline & Total & 37.0 \\
\hline & Substrate & Percent Cover \\
\hline & $\overline{\text { Sand }}$ & 65.0 \\
\hline & Rock & 0 \\
\hline & Leaf litter & 28.0 \\
\hline & Biologic soil crust & 7.00 \\
\hline
\end{tabular}


Table 9. Vegetation cover and substrate measured at Site 8 (Lower Y, Right)—Continued.

\begin{tabular}{lrr}
\hline Riverward Circle & Vegetation & Percent Cover \\
\hline \hline & Unidentified perennial grasses & 12.5 \\
& Willow (Salix exigua) & 5.50 \\
& Unidentified aster/composite & 0.50 \\
& Total & 18.5 \\
\cline { 2 - 3 } & Substrate & Percent Cover \\
\hline \hline Sand & 64.5 \\
Rock & 35.0 \\
Leaf litter & 0.50 \\
& Biologic soil crust & 0 \\
& \\
Total gap length on upstream/downstream transect (out of 4,000 cm): & \\
Total gap length on inland/riverward transect (out of 4,000 cm): & $1,435 \mathrm{~cm}$ \\
\hline Summary & \\
\hline \hline & \\
Total vegetation cover, in percent & 23.6 \\
Total sand substrate, in percent & \\
Total rock substrate, in percent & 75.0 \\
Total leaf litter substrate, in percent & 13.2 \\
Total biologic crust substrate, in percent & 10.4 \\
Total gap length, in percent & 1.50 \\
\hline
\end{tabular}


Table 10. Vegetation cover and substrate measured at Site 9 (Big Drop Beach, Left).

\begin{tabular}{|c|c|c|}
\hline \multirow[t]{2}{*}{ Center Circle } & \multirow{2}{*}{$\begin{array}{l}\text { Vegetation } \\
\text { Rice grass (Oryzopsis hymenoides) }\end{array}$} & Percent Cover \\
\hline & & 6.88 \\
\hline & Sand verbena (Abronia elliptica) & 6.50 \\
\hline & Wire lettuce (Stephanomeria pauciflora) & 6.50 \\
\hline & Long-leaf brickellbush (Brickellia longifolia) & 2.00 \\
\hline & Brome grasses (Bromus sp.) & 0.50 \\
\hline & Russian thistle (Salsola sp.) & 0.38 \\
\hline & Total & 22.8 \\
\hline & Substrate & Percent Cover \\
\hline & Sand & 98.5 \\
\hline & Rock & 0 \\
\hline & Leaf litter & 1.50 \\
\hline & Biologic soil crust & 0 \\
\hline \multirow[t]{12}{*}{ Upstream Circle } & Vegetation & Percent Cover \\
\hline & Rabbitbrush (Chrysothamnus sp.) & 9.00 \\
\hline & $\begin{array}{l}\text { Netleaf hackberry (Celtis laevigata) } \\
\text { Saltbush (Atriplex sp.) }\end{array}$ & 5.50 \\
\hline & Sand verbena (Abronia elliptica) & 1.70 \\
\hline & Brome grasses (Bromus sp.) & 1.50 \\
\hline & Dropseed (Sporobolus sp.) & 0.75 \\
\hline & Total & 21.5 \\
\hline & Substrate & Percent Cover \\
\hline & Sand & 64.3 \\
\hline & Rock & 0.50 \\
\hline & Leaf litter & 3.00 \\
\hline & Biologic soil crust & 32.2 \\
\hline
\end{tabular}


Table 10. Vegetation cover and substrate measured at Site 9 (Big Drop Beach, Left)—Continued.

\begin{tabular}{|c|c|c|}
\hline Downstream Circle & Vegetation & Percent Cover \\
\hline & Rice grass (Oryzopsis hymenoides) & 3.20 \\
\hline & Prince's plume (Stanleya pinnata) & 2.00 \\
\hline & Wire lettuce (Stephanomeria pauciflora) & 1.00 \\
\hline & Russian thistle (Salsola sp.) & 0.55 \\
\hline & Sand verbena (Abronia elliptica) & 0.15 \\
\hline & Unidentified annual grass & 0.10 \\
\hline & Total & 7.00 \\
\hline & Substrate & Percent Cover \\
\hline & $\overline{\text { Sand }}$ & 92.0 \\
\hline & Rock & 6.00 \\
\hline & Leaf litter & 2.00 \\
\hline & Biologic soil crust & 0 \\
\hline Inland Circle & Vegetation & Percent Cover \\
\hline & Rabbitbrush (Chrysothamnus sp.) & 17.5 \\
\hline & Ephedra (Ephedra sp.) & 12.5 \\
\hline & Prince's plume (Stanleya pinnata) & 3.00 \\
\hline & Saltbush (Atriplex sp.) & 2.50 \\
\hline & Rabbitbrush (Chrysothamnus sp.), dead & 1.75 \\
\hline & Total & 37.3 \\
\hline & Substrate & Percent Cover \\
\hline & $\overline{\text { Sand }}$ & 3.00 \\
\hline & Rock & 6.50 \\
\hline & Leaf litter & 40.0 \\
\hline & Biologic soil crust & 50.5 \\
\hline
\end{tabular}


Table 10. Vegetation cover and substrate measured at Site 9 (Big Drop Beach, Left)—Continued.

\begin{tabular}{|c|c|c|}
\hline Riverward Circle & Vegetation & Percent Cover \\
\hline & Long-leaf brickellbush (Brickellia longifolia) & 16.5 \\
\hline & Wire lettuce (Stephanomeria pauciflora) & 4.50 \\
\hline & Rice grass (Oryzopsis hymenoides) & 3.50 \\
\hline & Brome grasses (Bromus sp.) & 1.50 \\
\hline & Dropseed (Sporobolus sp.) & 1.00 \\
\hline & Total & 27.0 \\
\hline & Substrate & Percent Cover \\
\hline & Sand & 777.5 \\
\hline & Rock & 15.5 \\
\hline & Leaf litter & 7.00 \\
\hline & Biologic soil crust & 0 \\
\hline \multirow{2}{*}{\multicolumn{2}{|c|}{$\begin{array}{l}\text { Total gap length on upstream/downstream transect (out of 2,000 cm): } \\
\text { Total gap length on inland/riverward transect (out of } 2,000 \mathrm{~cm} \text { ): }\end{array}$}} & $1,569 \mathrm{~cm}$ \\
\hline & & $1,072 \mathrm{~cm}$ \\
\hline \multicolumn{3}{|l|}{ Summary } \\
\hline \multicolumn{2}{|c|}{ Total vegetation cover, in percent } & 23.1 \\
\hline \multicolumn{2}{|c|}{ Total sand substrate, in percent } & 67.1 \\
\hline \multicolumn{2}{|c|}{ Total rock substrate, in percent } & 5.70 \\
\hline \multicolumn{2}{|c|}{ Total leaf litter substrate, in percent } & 10.7 \\
\hline \multicolumn{2}{|c|}{ Total biologic crust substrate, in percent } & 16.5 \\
\hline \multicolumn{2}{|c|}{ Total gap length, in percent } & 66.0 \\
\hline
\end{tabular}


Table 11. Vegetation cover and substrate measured at Site 10 (Upper 25, Right).

\begin{tabular}{|c|c|c|}
\hline Center Circle & Vegetation & Percent Cover \\
\hline & Rice grass (Oryzopsis hymenoides) & 13.0 \\
\hline & Long-leaf brickellbush (Brickellia longifolia) & 6.00 \\
\hline & Squawbush (Rhus sp.) & 5.00 \\
\hline & Snakeweed (Gutierrezzia sp.) & 3.50 \\
\hline & Wire lettuce (Stephanomeria pauciflora) & 2.50 \\
\hline & Total & 30.0 \\
\hline & Substrate & Percent Cover \\
\hline & Sand & 84.8 \\
\hline & Rock & 14.8 \\
\hline & Leaf litter & 0.50 \\
\hline & Biologic soil crust & 0 \\
\hline Upstream Circle & Vegetation & Percent Cover \\
\hline & "Long-leaf brickellbush (Brickellia longifolia) & 9.00 \\
\hline & Netleaf hackberry (Celtis laevigata) & 5.00 \\
\hline & Rice grass (Oryzopsis hymenoides) & 3.50 \\
\hline & Snakeweed (Gutierrezzia sp.) & 2.75 \\
\hline & Needle-and-thread (Stipa comata) & 2.00 \\
\hline & Russian thistle (Salsola sp.) & 0.50 \\
\hline & Total & 22.8 \\
\hline & Substrate & Percent Cover \\
\hline & Sand & 59.9 \\
\hline & Rock & 40.0 \\
\hline & Leaf litter & 0.10 \\
\hline & Biologic soil crust & 0 \\
\hline
\end{tabular}


Table 11. Vegetation cover and substrate measured at Site 10 (Upper 25, Right)-Continued.

\begin{tabular}{|c|c|c|}
\hline \multirow[t]{15}{*}{ Downstream Circle } & Vegetation & Percent Cover \\
\hline & Netleaf hackberry (Celtis laevigata) & 6.50 \\
\hline & Wire lettuce (Stephanomeria pauciflora) & 6.00 \\
\hline & Unidenfied perennial forb & 5.00 \\
\hline & Rice grass (Oryzopsis hymenoides) & 3.50 \\
\hline & Needle-and-thread (Stipa comata) & 1.75 \\
\hline & Snakeweed (Gutierrezzia sp.) & 1.00 \\
\hline & Unidentified aster/composite & 0.50 \\
\hline & Russian thistle (Salsola sp.) & 0.25 \\
\hline & Total & 24.5 \\
\hline & Substrate & Percent Cover \\
\hline & Sand & 82.4 \\
\hline & Rock & 11.5 \\
\hline & Leaf litter & 6.00 \\
\hline & Biologic soil crust & 0.10 \\
\hline \multirow[t]{13}{*}{ Inland Circle } & Vegetation & Percent Cover \\
\hline & Squawbush (Rhus sp.) & 18.0 \\
\hline & Needle-and-thread (Stipa comata) & 13.5 \\
\hline & Brome grasses (Bromus sp.) & 1.00 \\
\hline & Snakeweed (Gutierrezzia sp.) & 0.75 \\
\hline & Wire lettuce (Stephanomeria pauciflora) & 0.40 \\
\hline & Rice grass (Oryzopsis hymenoides) & 0.30 \\
\hline & Total & 34.0 \\
\hline & Substrate & Percent Cover \\
\hline & Sand & 50.0 \\
\hline & Rock & 25.0 \\
\hline & Leaf litter & 10.0 \\
\hline & Biologic soil crust & 15.0 \\
\hline
\end{tabular}


Table 11. Vegetation cover and substrate measured at Site 10 (Upper 25, Right)-Continued.

\begin{tabular}{llr}
\hline Riverward Circle & Vegetation & Percent Cover \\
\hline \hline & Rice grass (Oryzopsis hymenoides) & 1.00 \\
& Total & 1.00 \\
& & \\
\cline { 2 - 3 } Substrate & Percent Cover \\
\hline \hline Sand & 51.5 \\
Rock & 45.0 \\
Leaf litter & 3.50 \\
Biologic soil crust & 0
\end{tabular}

Total gap length on upstream/downstream transect (out of 2,000 cm): $\quad 1,678 \mathrm{~cm}$

Total gap length on inland/riverward transect (out of 2,000 cm): $\quad 1,072 \mathrm{~cm}$

Summary

$\begin{array}{ll}\text { Total vegetation cover, in percent } & 22.4\end{array}$

$\begin{array}{lr}\text { Total sand substrate, in percent } & 65.7\end{array}$

Total rock substrate, in percent $\quad 27.3$

Total leaf litter substrate, in percent $\quad 4.02$

$\begin{array}{ll}\text { Total biologic crust substrate, in percent } & 3.02\end{array}$

Total gap length, in percent $\quad 68.8$ 
Table 12. Vegetation cover and substrate measured at Site 11 (Lower 25, Right).

\begin{tabular}{|c|c|c|}
\hline \multirow[t]{15}{*}{ Center Circle } & Vegetation & Percent Cover \\
\hline & Russian thistle (Salsola sp.) & 6.00 \\
\hline & Sand verbena (Abronia elliptica) & 4.50 \\
\hline & Unidentified perennial forb & 4.00 \\
\hline & Rice grass (Oryzopsis hymenoides) & 3.50 \\
\hline & Unidentified perennial forb, dead & 3.50 \\
\hline & Brome grasses (Bromus sp.) & 1.50 \\
\hline & Needle-and-thread (Stipa comata) & 1.50 \\
\hline & Pale evening primrose (Oenothera pallida) & 0.75 \\
\hline & Total & 25.3 \\
\hline & Substrate & Percent Cover \\
\hline & Sand & 92.9 \\
\hline & Rock & 0 \\
\hline & Leaf litter & 7.00 \\
\hline & Biologic soil crust & 0.10 \\
\hline \multirow[t]{18}{*}{ Upstream Circle } & Vegetation & Percent Cover \\
\hline & Needle-and-thread (Stipa comata) & 7.50 \\
\hline & Unidentified perennial forb & 6.75 \\
\hline & Unidentified shrub, dead & 3.00 \\
\hline & Unidentified legume & 1.25 \\
\hline & Wire lettuce (Stephanomeria pauciflora) & 1.00 \\
\hline & Russian thistle (Salsola sp.) & 0.75 \\
\hline & Rice grass (Oryzopsis hymenoides) & 0.50 \\
\hline & Unidentified annual grass & 0.50 \\
\hline & Dropseed (Sporobolus sp.) & 0.50 \\
\hline & Sand verbena (Abronia elliptica) & 0.25 \\
\hline & Unidentified aster/composite & 0.10 \\
\hline & Total & 14.6 \\
\hline & Substrate & Percent Cover \\
\hline & Sand & 83.5 \\
\hline & Rock & 6.50 \\
\hline & Leaf litter & 0 \\
\hline & Biologic soil crust & 10.0 \\
\hline
\end{tabular}


Table 12. Vegetation cover and substrate measured at Site 11 (Lower 25, Right)—Continued.

\begin{tabular}{|c|c|c|}
\hline \multirow[t]{2}{*}{ Downstream Circle } & \multirow{2}{*}{$\begin{array}{l}\text { Vegetation } \\
\text { Unidentified forbs }\end{array}$} & Percent Cover \\
\hline & & 16.3 \\
\hline & Unidentified perennial forb, dead & 7.00 \\
\hline & Russian thistle (Salsola sp.) & 3.50 \\
\hline & Rice grass (Oryzopsis hymenoides) & 1.00 \\
\hline & Sand verbena (Abronia elliptica) & 0.50 \\
\hline & Dropseed (Sporobolus sp.) & 0.50 \\
\hline & Globemallow (Sphaeralcea sp.) & 0.25 \\
\hline & Total & 29.0 \\
\hline & Substrate & Percent Cover \\
\hline & Sand & 92.0 \\
\hline & Rock & 0 \\
\hline & Leaf litter & 5.50 \\
\hline & Biologic soil crust & 2.50 \\
\hline \multirow[t]{10}{*}{ Inland Circle } & Vegetation & Percent Cover \\
\hline & Ephedra (Ephedra sp.) & (55.0 \\
\hline & Rice grass (Oryzopsis hymenoides) & 1.25 \\
\hline & Brome grasses (Bromus sp.) & 0.25 \\
\hline & Total & 56.5 \\
\hline & Substrate & Percent Cover \\
\hline & Sand & 10.0 \\
\hline & Rock & 20.0 \\
\hline & Leaf litter & 50.0 \\
\hline & Biologic soil crust & 20.0 \\
\hline
\end{tabular}


Table 12. Vegetation cover and substrate measured at Site 11 (Lower 25, Right)-Continued.

\begin{tabular}{|c|c|c|}
\hline Riverward Circle & Vegetation & Percent Cover \\
\hline & Rice grass (Oryzopsis hymenoides) & 3.00 \\
\hline & Unidentified perennial grass & 2.50 \\
\hline & Wire lettuce (Stephanomeria pauciflora) & 1.75 \\
\hline & Brome grasses (Bromus sp.) & 1.50 \\
\hline & Russian thistle (Salsola sp.) & 1.00 \\
\hline & Ephedra (Ephedra sp.) & 0.50 \\
\hline & Globemallow (Sphaeralcea sp.) & 0.50 \\
\hline & Total & 10.8 \\
\hline & Substrate & Percent Cover \\
\hline & Sand & 37.5 \\
\hline & Rock & 55.0 \\
\hline & Leaf litter & 3.00 \\
\hline & Biologic soil crust & 4.50 \\
\hline \multirow{2}{*}{\multicolumn{2}{|c|}{$\begin{array}{l}\text { Total gap length on upstream/downstream transect (out of } 4,000 \mathrm{~cm} \text { ): } \\
\text { Total gap length on inland/riverward transect (out of } 4,000 \mathrm{~cm} \text { ): }\end{array}$}} & $2,618 \mathrm{~cm}$ \\
\hline & & $2,829 \mathrm{~cm}$ \\
\hline
\end{tabular}

$\begin{array}{ll}\text { Total vegetation cover, in percent } & 28.7\end{array}$

Total sand substrate, in percent $\quad 63.2$

Total rock substrate, in percent $\quad 16.3$

Total leaf litter substrate, in percent $\quad 13.1$

$\begin{array}{ll}\text { Total biologic crust substrate, in percent } & 7.42\end{array}$

\begin{tabular}{lc} 
Total gap length, in percent & 68.1 \\
\hline
\end{tabular} 
Table 13. Vegetation cover and substrate measured at Site 12 (Ten Cent Camp, Left).

\begin{tabular}{|c|c|c|}
\hline Center Circle & Vegetation & Percent Cover \\
\hline & Netleaf hackberry (Celtis laevigata) & 8.00 \\
\hline & Unidentified perennial forb & 7.50 \\
\hline & Wire lettuce (Stephanomeria pauciflora) & 3.50 \\
\hline & Apache plume (Fallugia paradoxa) & 2.50 \\
\hline & Rice grass (Oryzopsis hymenoides) & 1.50 \\
\hline & Unidentified perennial grass & 0.50 \\
\hline & Total & 23.5 \\
\hline & Substrate & Percent Cover \\
\hline & Sand & 51.5 \\
\hline & Rock & 46.0 \\
\hline & Leaf litter & 2.50 \\
\hline & Biologic soil crust & 0 \\
\hline Upstream Circle & Vegetation & Percent Cover \\
\hline & Unidentified perennial forb & $\begin{array}{l}10.0 \\
\end{array}$ \\
\hline & Apache plume (Fallugia paradoxa) & 6.00 \\
\hline & Unidentified legume & 1.00 \\
\hline & Unidentified aster/composite & 0.75 \\
\hline & Rice grass (Oryzopsis hymenoides) & 0.75 \\
\hline & Netleaf hackberry (Celtis laevigata) & 0.50 \\
\hline & Wire lettuce (Stephanomeria pauciflora) & 0.25 \\
\hline & Brome grasses (Bromus sp.) & 0.25 \\
\hline & Needle-and-thread (Stipa comata) & 0.20 \\
\hline & Total & 19.7 \\
\hline & Substrate & Percent Cover \\
\hline & Sand & 84.0 \\
\hline & Rock & 15.0 \\
\hline & Leaf litter & 1.00 \\
\hline & Biologic soil crust & 0 \\
\hline
\end{tabular}


Table 13. Vegetation cover and substrate measured at Site 12 (Ten Cent Camp, Left)—Continued.

\begin{tabular}{|c|c|c|}
\hline \multirow[t]{13}{*}{ Downstream Circle } & Vegetation & Percent Cover \\
\hline & Apache plume (Fallugia paradoxa) & 8.50 \\
\hline & Unidentified shrub & 7.00 \\
\hline & Rice grass (Oryzopsis hymenoides) & 5.00 \\
\hline & Wire lettuce (Stephanomeria pauciflora) & 5.00 \\
\hline & Unidentified legume & 4.00 \\
\hline & Netleaf hackberry (Celtis laevigata) & 2.75 \\
\hline & Total & 32.3 \\
\hline & Substrate & Percent Cover \\
\hline & Sand & 89.3 \\
\hline & Rock & 10.0 \\
\hline & Leaf litter & 0.75 \\
\hline & Biologic soil crust & 0 \\
\hline \multirow[t]{11}{*}{ Inland Circle } & Vegetation & Percent Cover \\
\hline & Apache plume (Fallugia paradoxa) & 35.0 \\
\hline & Netleaf hackberry (Celtis laevigata) & 1.50 \\
\hline & Brome grasses (Bromus sp.) & 0.50 \\
\hline & Unidentified aster/composite & 0.10 \\
\hline & Total & 37.1 \\
\hline & Substrate & Percent Cover \\
\hline & Sand & 71.0 \\
\hline & Rock & 4.00 \\
\hline & Leaf litter & 5.00 \\
\hline & Biologic soil crust & 20.0 \\
\hline
\end{tabular}


Table 13. Vegetation cover and substrate measured at Site 12 (Ten Cent Camp, Left)—Continued.

\begin{tabular}{|c|c|c|}
\hline Riverward Circle & Vegetation & Percent Cover \\
\hline & Netleaf hackberry (Celtis laevigata) & 30.0 \\
\hline & Wire lettuce (Stephanomeria pauciflora) & 5.50 \\
\hline & Rice grass (Oryzopsis hymenoides) & 1.00 \\
\hline & Brome grasses (Bromus sp.) & 1.00 \\
\hline & Unidentified perennial grass & 0.50 \\
\hline & Total & 38.0 \\
\hline & Substrate & Percent Cover \\
\hline & 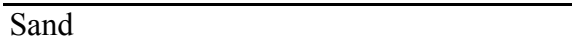 & $\overline{54.0}$ \\
\hline & Rock & 45.0 \\
\hline & Leaf litter & 1.00 \\
\hline & Biologic soil crust & 0 \\
\hline \multirow{2}{*}{\multicolumn{2}{|c|}{$\begin{array}{l}\text { Total gap length on upstream/downstream transect (out of } 2,000 \mathrm{~cm} \text { ): } \\
\text { Total gap length on inland/riverward transect (out of } 2,000 \mathrm{~cm} \text { ): }\end{array}$}} & $1,606 \mathrm{~cm}$ \\
\hline & & $1,426 \mathrm{~cm}$ \\
\hline \multicolumn{3}{|l|}{ Summary } \\
\hline \multicolumn{2}{|c|}{ Total vegetation cover, in percent } & 30.1 \\
\hline \multicolumn{2}{|c|}{ Total sand substrate, in percent } & 70.0 \\
\hline \multicolumn{2}{|c|}{ Total rock substrate, in percent } & 24.0 \\
\hline \multicolumn{2}{|c|}{ Total leaf litter substrate, in percent } & 2.05 \\
\hline \multicolumn{2}{|c|}{ Total biologic crust substrate, in percent } & 4.00 \\
\hline \multicolumn{2}{|c|}{ Total gap length, in percent } & 75.8 \\
\hline
\end{tabular}


Table 14. Vegetation cover and substrate measured at Site 13 (Lower Ten Cent, Left).

\begin{tabular}{|c|c|c|}
\hline \multirow[t]{2}{*}{ Center Circle } & \multirow{2}{*}{$\begin{array}{l}\text { Vegetation } \\
\text { Unidentified perennial grass }\end{array}$} & Percent Cover \\
\hline & & 10.5 \\
\hline & Ephedra (Ephedra sp.) & 5.50 \\
\hline & Needle-and-thread (Stipa comata) & 2.00 \\
\hline & Russian thistle (Salsola sp.) & 1.00 \\
\hline & Unidentified forbs & 0.70 \\
\hline & Sand verbena (Abronia elliptica) & 0.50 \\
\hline & Rice grass (Oryzopsis hymenoides) & 0.50 \\
\hline & Brome grasses (Bromus sp.) & 0.50 \\
\hline & Bindweed heliotrope (Heliotropium convolvulaceum) & 0.10 \\
\hline & Total & 21.3 \\
\hline & Substrate & Percent Cover \\
\hline & Sand & 86.5 \\
\hline & Rock & 0 \\
\hline & Leaf litter & 3.50 \\
\hline & Biologic soil crust & 10.0 \\
\hline \multirow[t]{15}{*}{ Upstream Circle } & Vegetation & Percent Cover \\
\hline & Ephedra (Ephedra sp.) & 7.25 \\
\hline & Needle-and-thread (Stipa comata) & 2.75 \\
\hline & Rice grass (Oryzopsis hymenoides) & 2.25 \\
\hline & Dicoria (Dicoria canescens) & 1.50 \\
\hline & Spike dropseed (Sporobolus contractus) & 0.90 \\
\hline & Dropseed (Sporobolus sp.) & 0.60 \\
\hline & Unidentified perennial grass, dead & 0.50 \\
\hline & Sand verbena (Abronia elliptica) & 0.40 \\
\hline & Bindweed heliotrope (Heliotropium convolvulaceum) & 0.20 \\
\hline & Total & 16.4 \\
\hline & Substrate & Percent Cover \\
\hline & $\begin{array}{l}\text { Sand } \\
\text { San }\end{array}$ & $\begin{array}{lc}100 \\
\end{array}$ \\
\hline & Rock & 0 \\
\hline & $\begin{array}{l}\text { Leaf litter } \\
\text { Biologic soil crust }\end{array}$ & 0 \\
\hline
\end{tabular}


Table 14. Vegetation cover and substrate measured at Site 13 (Lower Ten Cent, Left)—Continued.

\begin{tabular}{|c|c|c|}
\hline \multirow[t]{16}{*}{ Downstream Circle } & Vegetation & Percent Cover \\
\hline & Ephedra (Ephedra sp.) & 9.00 \\
\hline & Unidentified perennial grasses & 8.50 \\
\hline & Wire lettuce (Stephanomeria pauciflora) & 6.50 \\
\hline & Needle-and-thread (Stipa comata) & 4.25 \\
\hline & Russian thistle (Salsola sp.) & 0.75 \\
\hline & Sand verbena (Abronia elliptica) & 0.50 \\
\hline & Unidentified annual grass & 0.25 \\
\hline & Brome grasses (Bromus sp.) & 0.13 \\
\hline & Bindweed heliotrope (Heliotropium convolvulaceum) & 0.10 \\
\hline & Total & 30.0 \\
\hline & Substrate & Percent Cover \\
\hline & Sand & 93.5 \\
\hline & Rock & 0 \\
\hline & Leaf litter & 5.50 \\
\hline & Biologic soil crust & 1.00 \\
\hline \multirow[t]{18}{*}{ Inland Circle } & Vegetation & Percent Cover \\
\hline & Ephedra (Ephedra sp.) & 10.0 \\
\hline & Unidentified perennial grass & 7.00 \\
\hline & Unidentified annual grass & 4.00 \\
\hline & Unidentified perennial grass, dead & 3.25 \\
\hline & Russian thistle (Salsola sp.) & 2.88 \\
\hline & Needle-and-thread (Stipa comata) & 2.50 \\
\hline & Wire lettuce (Stephanomeria pauciflora) & 2.50 \\
\hline & Rice grass (Oryzopsis hymenoides) & 1.75 \\
\hline & Sand verbena (Abronia elliptica) & 0.50 \\
\hline & Unidentified forb & 0.20 \\
\hline & Brome grasses (Bromus sp.) & 0.10 \\
\hline & Total & 34.7 \\
\hline & Substrate & Percent Cover \\
\hline & Sand & 92.5 \\
\hline & Rock & 0 \\
\hline & Leaf litter & 4.50 \\
\hline & Biologic soil crust & 3.00 \\
\hline
\end{tabular}


Table 14. Vegetation cover and substrate measured at Site 13 (Lower Ten Cent, Left)—Continued.

\begin{tabular}{llr}
\hline Riverward Circle & Vegetation & Percent Cover \\
\hline \hline & Rice grass (Oryzopsis hymenoides) & 5.50 \\
& Russian thistle (Salsola sp.) & 3.50 \\
Sand verbena (Abronia elliptica) & 1.50 \\
Needle-and-thread (Stipa comata) & 1.00 \\
Unidentified perennial grass & 1.00 \\
Bindweed heliotrope (Heliotropium convolvulaceum) & 0.38 \\
Brome grasses (Bromus sp.) & 0.10 \\
Unidentified legume & 0.10 \\
& \\
& Total & 13.1 \\
& \\
\cline { 2 - 2 } & Percent Cover \\
\hline \hline Sand & 98.9 \\
Rock & 0.10 \\
Leaf litter & 1.00 \\
Biologic soil crust & 0
\end{tabular}

Total gap length on upstream/downstream transect (out of 2,000 cm): $\quad 1,547 \mathrm{~cm}$ Total gap length on inland/riverward transect (out of 2,000 cm): $\quad 1,671 \mathrm{~cm}$

Summary

Total vegetation cover, in percent

Total sand substrate, in percent

Total rock substrate, in percent

Total leaf litter substrate, in percent

2.90

Total biologic crust substrate, in percent

2.80

Total gap length, in percent 80.5 